Prepared in cooperation with the Alaska Department of Transportation and Public Facilities

\title{
Hydrology and Modeling of Flow Conditions at Bridge 339 and Mile 38-43, Copper River Highway, Alaska
}

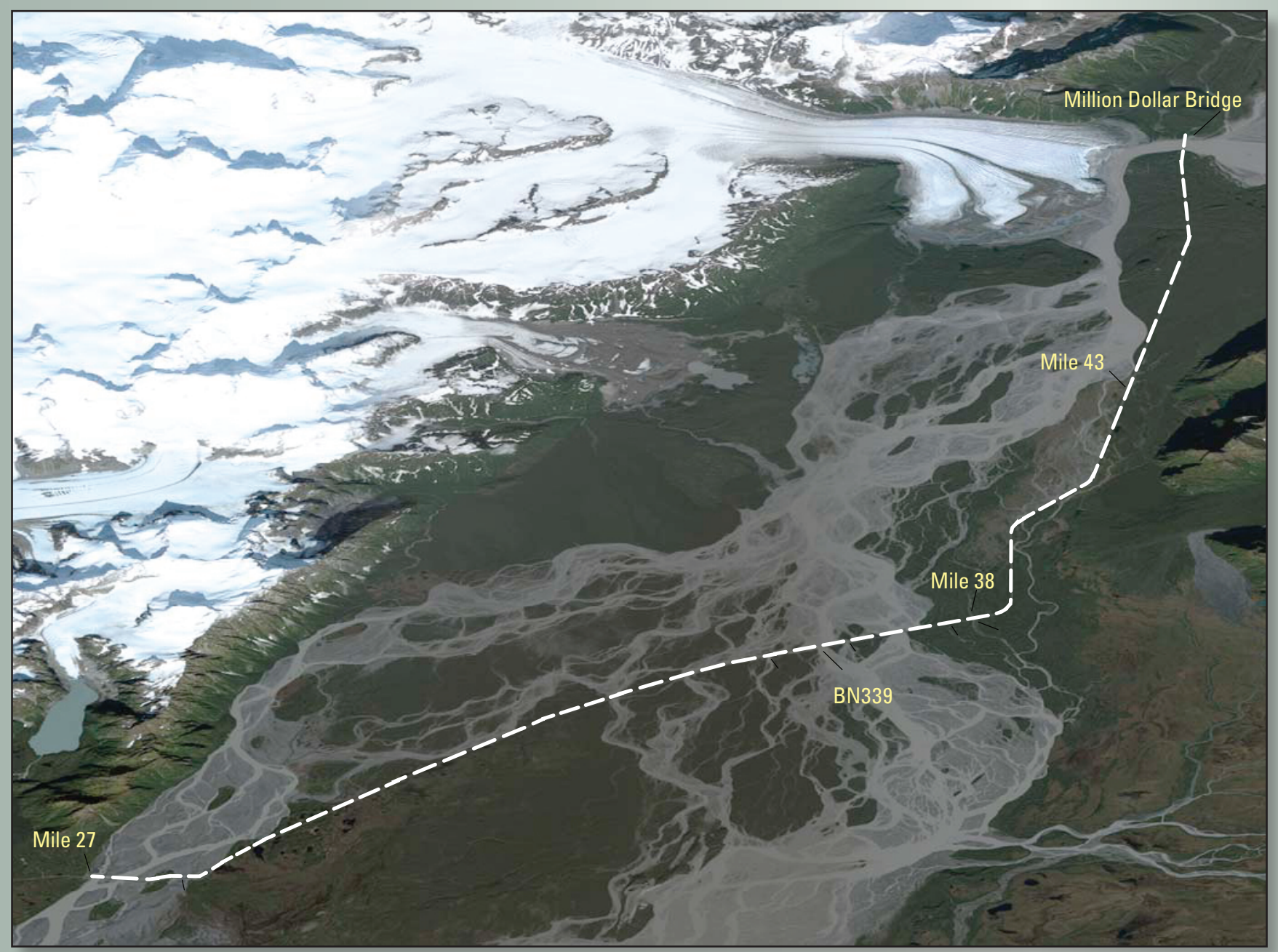

Scientific Investigations Report 2012-5153 
Cover: Photograph of the Copper River Highway from Mile 27 (Flag Point) to the Million Dollar Bridge. (Photograph taken by DigitalGlobe ${ }^{\circledR}$, September 25, 2011. Used with permission.) 


\section{Hydrology and Modeling of Flow Conditions at Bridge 339 and Mile 38-43, Copper River Highway, Alaska}

By Timothy P. Brabets

Prepared in cooperation with the Alaska Department of Transportation and

Public Facilities

Scientific Investigations Report 2012-5153 


\title{
U.S. Department of the Interior \\ KEN SALAZAR, Secretary \\ U.S. Geological Survey \\ Marcia K. McNutt, Director
}

\author{
U.S. Geological Survey, Reston, Virginia: 2012
}

For more information on the USGS - the Federal source for science about the Earth, its natural and living resources, natural hazards, and the environment, visit http://www.usgs.gov or call 1-888-ASK-USGS.

For an overview of USGS information products, including maps, imagery, and publications, visit http://www.usgs.gov/pubprod

To order this and other USGS information products, visit http://store.usgs.gov

Any use of trade, product, or firm names is for descriptive purposes only and does not imply endorsement by the U.S. Government.

Although this report is in the public domain, permission must be secured from the individual copyright owners to reproduce any copyrighted materials contained within this report.

Suggested citation:

Brabets, T.P., 2012, Hydrology and modeling of flow conditions at Bridge 339 and Mile 38-43, Copper River Highway, Alaska: U.S. Geological Survey Scientific Investigations Report 2012-5153, 26 p. 


\section{Contents}

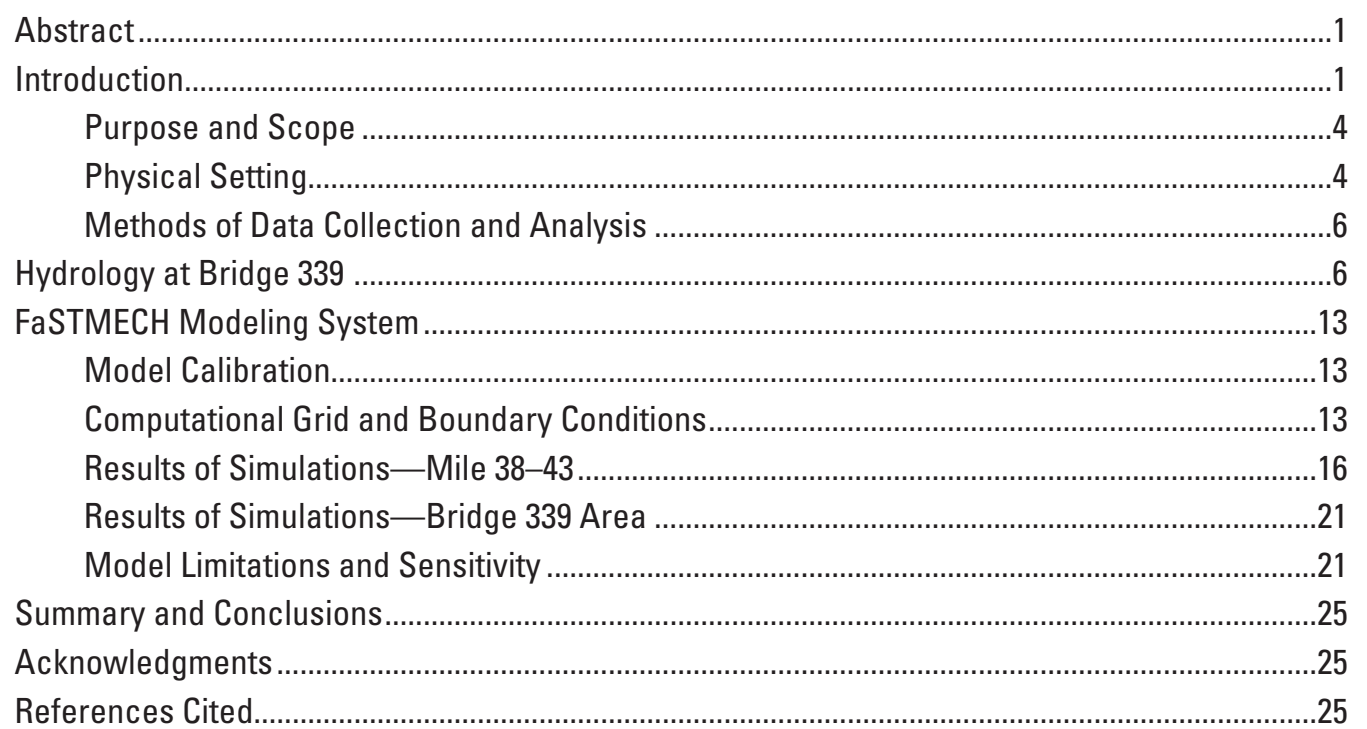




\section{Figures}

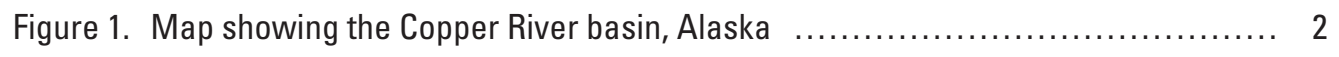

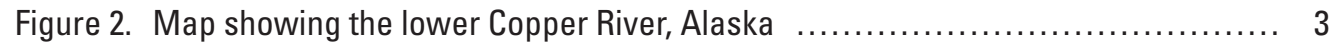

Figure 3. Map showing locations of bridges along the Copper River Highway, Alaska $\ldots \ldots . \quad 5$

Figure 4. LiDAR data from 2009 overlaid on aerial photograph from 2006 showing channel changes at Bridge 339 and Bridge 342, Copper River Highway, Alaska........... 7

Figure 5. Graph showing percentage of total flow passing through Bridges 339 and 342 during open water period, Copper River Highway, Alaska, from June 2010 to September 2010 and 2011

Figure 6. Hydrographs showing flow at the Copper River at the Million Dollar Bridge, and measurements and soundings at Bridge 339, Copper River Highway, Alaska, May 1 to September 30, 2010, and 2011 ....

Figure 7. Cross section showing scour at Bridge 339, Copper River Highway, Alaska, June 1 and September 14, 2011

Figure 8. Maps showing LiDAR data from November 7-10, 2009, and aerial photograph from October 4, 2011, at Bridges 339 and 342, Copper River Highway, Alaska ..... 11

Figure 9. Map showing LiDAR data from 2009 overlaid on aerial photographs from 2006 near the Mile 38-43 area, Copper River Highway, Alaska

Figure 10. Aerial photograph showing approximate outline of computational grid for FaSTMECH, Mile 38-43, Copper River Highway, Alaska 15

Figure 11. Aerial photograph showing approximate outline of computational grid for FaSTMECH for Bridge 339 area, Copper River Highway, Alaska

Figure 12. Map showing output from FaSTMECH of water-surface elevation at Mile 38-43 for a flow of 116,000 cubic feet per second, Copper River Highway, Alaska .... 18

Figure 13. Map showing output from FaSTMECH of water-surface elevation at Mile 38-43 for a flow of 174,000 cubic feet per second, Copper River Highway, Alaska 19

Figure 14. Map showing output from FaSTMECH of water-surface elevation at Mile 38-43 for a flow of 400,000 cubic feet per second, Copper River Highway, Alaska 20

Figure 15. Maps showing output from FaSTMECH showing depth of water for flows of 50,000 and 100,000 cubic feet per second for the Bridge 339 area, Copper River Highway, Alaska

Figure 16. Maps showing output from FaSTMECH showing water-surface elevation for flows of 50,000 and 100,000 cubic feet per second for the Bridge 339 area,

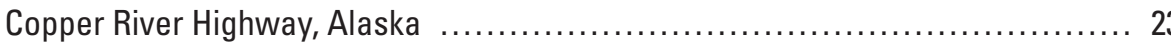

Figure 17. Map showing output from FaSTMECH showing shear stress for a flow of 100,000 cubic feet per second for the Bridge 339 area, Copper River Highway, Alaska..... 24

\section{Tables}

Table 1. Flow measurements and percentage of total flow at Bridge 339, Bridge 342, and the Million Dollar Bridge, Copper River Highway, Alaska, 2010-11

Table 2. Input values for flow scenarios in FaSTMECH for Mile 38-43 of Copper River Highway, Alaska 


\section{Conversion Factors and Datums}

Conversion Factors

\begin{tabular}{|c|c|c|}
\hline Multiply & By & To obtain \\
\hline \multicolumn{3}{|c|}{ Length } \\
\hline inch (in.) & 25.4 & millimeter (mm) \\
\hline foot $(\mathrm{ft})$ & 0.3048 & meter $(\mathrm{m})$ \\
\hline mile (mi) & 1.609 & kilometer (km) \\
\hline \multicolumn{3}{|c|}{ Area } \\
\hline square foot $\left(\mathrm{ft}^{2}\right)$ & 0.09290 & square meter $\left(\mathrm{m}^{2}\right)$ \\
\hline square mile $\left(\mathrm{mi}^{2}\right)$ & 2.590 & square kilometer $\left(\mathrm{km}^{2}\right)$ \\
\hline \multicolumn{3}{|c|}{ Flow rate } \\
\hline foot per second (ft/s) & 0.3048 & meter per second $(\mathrm{m} / \mathrm{s})$ \\
\hline cubic foot per second $\left(\mathrm{ft}^{3} / \mathrm{s}\right)$ & 0.02832 & cubic meter per second $\left(\mathrm{m}^{3} / \mathrm{s}\right)$ \\
\hline $\begin{array}{l}\text { cubic foot per second per square mile } \\
\qquad\left[\left(\mathrm{ft}^{3} / \mathrm{s}\right) / \mathrm{mi}^{2}\right]\end{array}$ & 0.01093 & $\begin{array}{l}\text { cubic meter per second per } \\
\text { square kilometer }\left[\left(\mathrm{m}^{3} / \mathrm{s}\right) / \mathrm{km}^{2}\right]\end{array}$ \\
\hline \multicolumn{3}{|c|}{ Hydraulic gradient } \\
\hline foot per mile (ft/mi) & 0.1894 & meter per kilometer $(\mathrm{m} / \mathrm{km})$ \\
\hline \multicolumn{3}{|c|}{ Shear stress } \\
\hline pound per square foot $\left(\mathrm{lb} / \mathrm{ft}^{2}\right)$ & 47.87 & Newtons per square meter \\
\hline \multicolumn{3}{|c|}{ Lateral eddy viscosity } \\
\hline foot squared per second $\left(\mathrm{ft}^{2} / \mathrm{s}\right)$ & 0.0929 & meter squared per second $\left(\mathrm{m}^{2} / \mathrm{s}\right)$ \\
\hline
\end{tabular}

Datums

Vertical coordinate information is referenced to the North American Vertical Datum of 1988 (NAVD 88).

Horizontal coordinate information is referenced to the North American Datum of 1983 (NAD 83).

Elevation, as used in this report, refers to distance above the vertical datum 
This page intentionally left blank. 


\title{
Hydrology and Modeling of Flow Conditions at Bridge 339 and Mile 38-43, Copper River Highway, Alaska
}

\author{
By Timothy P. Brabets
}

\section{Abstract}

The Copper River basin, the sixth largest watershed in Alaska, drains an area of 24,200 square miles in south-central Alaska. This large, glacier-fed river flows across a wide alluvial fan before it enters the Gulf of Alaska. The Copper River Highway, which traverses the alluvial fan, has been affected by channel planform reconfiguration. Currently (2012), two areas of the Copper River Highway are at risk: at Mile 38-43, the road grade is too low and the highway could be flooded by high flows of the Copper River, and at Mile 36, the main channel of the Copper River has migrated directly toward Bridge 339. Because Bridge 339 was not designed and built to convey the main flow of the Copper River, as much as 50 feet of scour occurred at the piers in 2011. The piers can no longer absorb the lateral or vertical loads, resulting in closure of the bridge and the Copper River Highway.

The U.S. Geological Survey Flow and $\underline{\text { Sediment }}$ Transport with Morphologic Evolution of Channels (FaSTMECH) model was used to simulate the flow of the Copper River and produce simulations of depth, water-surface elevation, and velocity. At the Mile 38-43 area, FaSTMECH was used to analyze the effects of raising the road grade 5 feet, and at Mile 36, FaSTMECH was used to analyze the effects of constructing a channel to divert flow away from Bridge 339. Results from FaSTMECH indicate that if raising the road grade 5 feet in the Mile 38-43 area, a flood with an annual exceedance probability of 2 percent $(400,000$ cubic feet per second) would not overtop the highway. In the Bridge 339 area, results from FaSTMECH indicate that a design channel could divert flows as much as 100,000 cubic feet per second away from Bridge 339.

\section{Introduction}

The Copper River basin, with a drainage area of $24,200 \mathrm{mi}^{2}$, is the sixth largest basin in Alaska. Its glaciated headwaters are in the Alaska Range to the north, the Wrangell-St. Elias Mountains to the east, and the Talkeetna
Mountains to the west (fig. 1). The Copper River flows southward to the Gulf of Alaska and is the only river that bisects the Chugach Mountains, which effectively divide the Copper River basin into two distinct climate types. The larger part of the basin is north of the Chugach Mountains, within the cold and arid continental climate of interior Alaska. South of the Chugach Mountains, a maritime climate with moderate temperatures and high precipitation prevails. The total length of the Copper River is approximately $290 \mathrm{mi}$ with an average gradient of about $12 \mathrm{ft} / \mathrm{mi}$ (Quinn, 1995). In the lower reach, near the mouth of the river, the average gradient is about $6 \mathrm{ft} / \mathrm{mi}$. Most of the valleys of the Copper River and its tributaries are incised in the Copper River lowlands, a relatively smooth plain that ranges in elevation from approximately 1,000 to 3,000 ft (Wahrhaftig, 1965). Glaciation has been the major force in creating present-day landforms in the basin. Glaciers and glacial lakes have at one time or another covered most of the area. In 2011, approximately 18 percent of the Copper River basin consisted of glaciers. During the winter months (November through April), the river is ice covered and flow averages $11,700 \mathrm{ft}^{3} / \mathrm{s}$ near the mouth. During the open-water months (May through October), however, glaciers contribute significant flow to the Copper River, increasing the average flow by an order of magnitude to $113,300 \mathrm{ft}^{3} / \mathrm{s}$ near the mouth. Additionally, the lower Copper River is subject to rapid increases in flow due to the breakout of numerous glacier-dammed lakes in the basin.

The lower Copper River flows into a large, relatively flat, alluvial plain near its mouth (ig. 2). As with many alluvial systems, the banks and streambeds of the lower Copper River are readily erodible and less permanent than most other aspects of the landscape. Mile 27 (Flag Point) to Mile 38 of the Copper River Highway crosses the alluvial plain. The highway originally was the Copper River and Northwestern Railway, which was built in 1907 from Cordova to the Kennecott copper mines (fig. 1). The railway ran until 1938 when the Kennecott mines closed. From 1945 to 1973, the rail bed gradually was converted to the Copper River Highway, beginning at Cordova and extending about $25 \mathrm{mi}$ past the Million Dollar Bridge (fig. 1). 

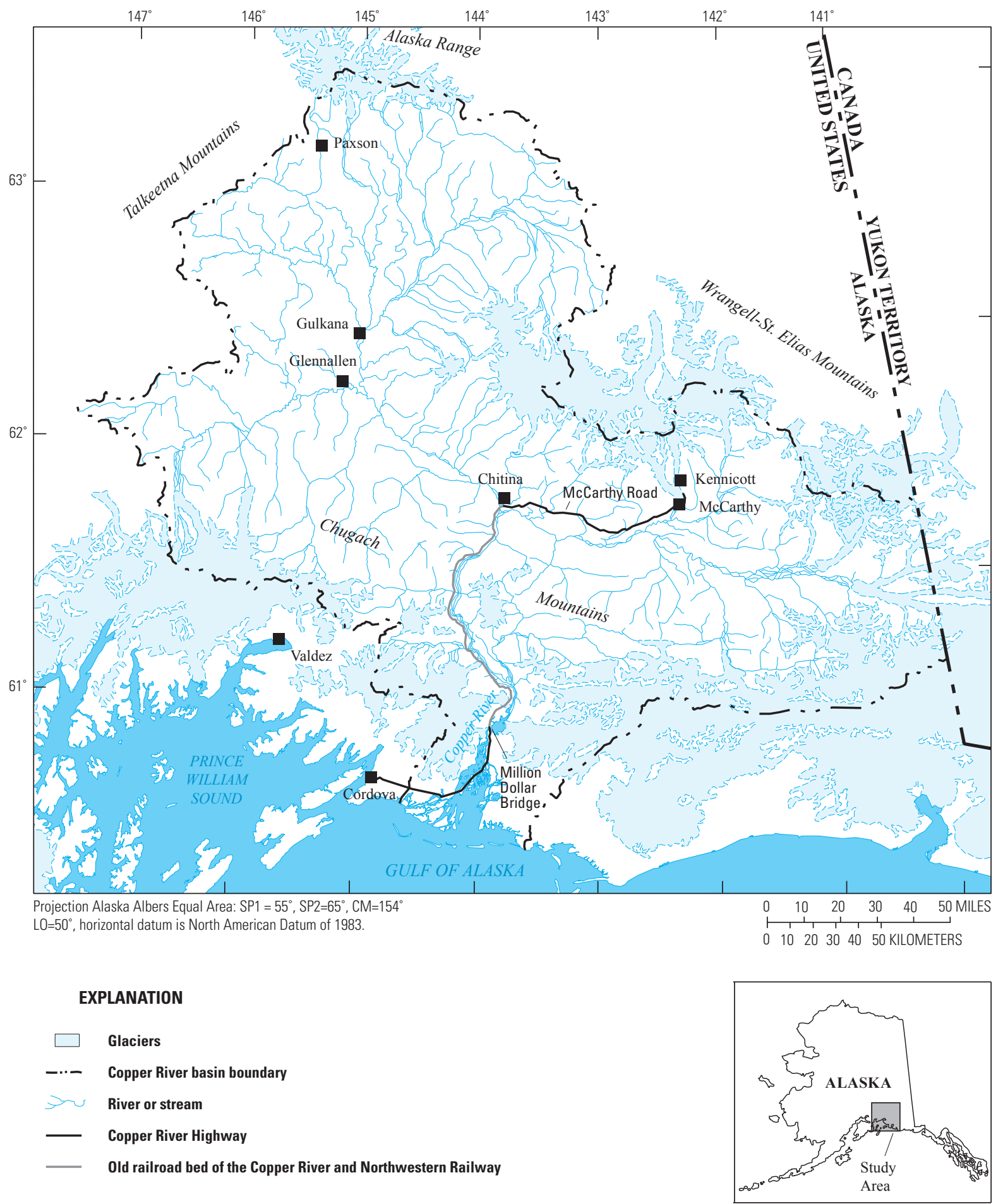

Figure 1. The Copper River basin, Alaska. 


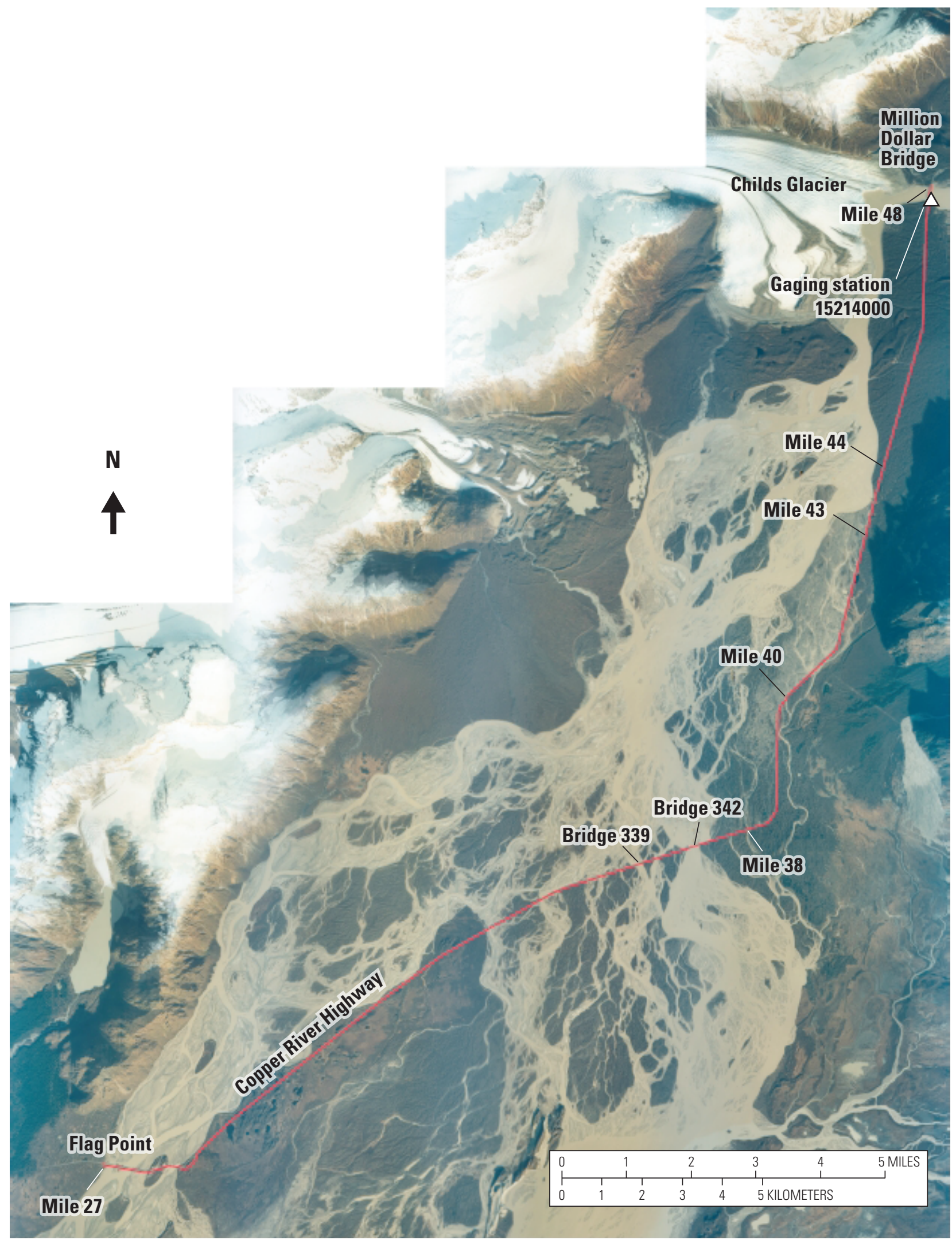

Aerial photograph taken by AeroMetric, Inc., October 15, 2006.

Figure 2. The lower Copper River, Alaska. 
After the March 1964 earthquake, reconstruction of the bridges between Flag Point and the Million Dollar Bridge began in 1970. At some locations along the highway where the Copper River had shifted away from the road, bridges were not rebuilt, and the bridge openings were filled in. When reconstruction along the delta was completed in 1978, 11 bridges (fig. 3) were located between Mile 27 (Flag Point) and Mile 38 of the highway, which crosses the alluvial plain of the lower Copper River. The lengths of the bridges (fig. 3 ) ranged from 240 to $1,200 \mathrm{ft}$. Three bridges at Flag Point were built on concrete piers and the remaining bridges were built on concrete-filled steel pilings. Spur dikes were constructed at some bridges to direct river flow perpendicular to the bridge opening. The north span of the Million Dollar Bridge was raised and repaired beginning in 2004 and was completed in 2005 .

Damage to the bridges and the road along the Copper River Highway can be directly attributed to the changes in the alluvial system of the lower Copper River. In a cooperative water resource study between Alaska Department of Transportation and Public Facilities (ADOT\&PF) and the U.S. Geological Survey (USGS), Brabets (1997) identified a major channel shift of the Copper River in the mid to late 1980s and early 1990s that resulted in a flow increase toward Bridge 342 (figs. 2 and 3 ). Approximately $\$ 10$ million was spent to (1) lengthen the bridge to $880 \mathrm{ft}$ to convey the increased flow and (2) to construct spur dikes to redirect the flow to a perpendicular alignment to the bridge. In another recent cooperative water resource study between ADOT\&PF and the USGS, Brabets and Conaway (2009) identified other channel changes: near Mile 44 (figs. 2 and 3 ), a channel change washed out a 3-4 mi stretch of the Copper River Highway and upstream near Mile 36, a channel change resulted in less flow toward the Flag Point bridges and more flow toward Bridge 339. As a result, Bridge 339 was added to the AKDOT\&PF scour-critical list. Another channel shift caused by the flood of October 2006 resulted in additional flow toward Bridge 339 . Bridge $339,400 \mathrm{ft}$ long when constructed, was originally designed to pass a maximum flow of $17,500 \mathrm{ft}^{3} / \mathrm{s}$. Flows as much as $85,500 \mathrm{ft}^{3} / \mathrm{s}$ were measured at Bridge 339 in 2011 . The high flows caused severe scour at numerous piers that resulted in the closure of the Copper River Highway at Bridge 339 in August 2011.

Because the streambed patterns of the lower Copper River are changing constantly, maintaining the Copper River Highway from Flag Point (Mile 27) to the Million Dollar Bridge (Mile 48) will continue to present challenges for ADOT\&PF, as channels near the bridges and highway continue to scour or fill, or move laterally. After expensive repairs have been made to the road or a bridge, the channel will often migrate away from the repaired area to another section of the road or another bridge and cause additional problems. Although difficult, the best approach is to anticipate future problem areas and then develop less expensive countermeasures before failure occurs. Recognizing this need, AKDOT\&PF entered into another cooperative water study with the USGS in October 2009.

\section{Purpose and Scope}

The purpose of this report is to document the current effects of flows in the Copper River on the Copper River Highway and assess possible construction projects to the highway. Two specific areas where damage recently (2012) occurred to the Copper River Highway were identified: (1) the area near Mile 38-43 and (2) the area near Bridge 339. In the Mile 38-43 area, AKDOT\&PF is considering raising the grade elevation of the road by $5 \mathrm{ft}$. The Bridge 339 area is undergoing dynamic channel changes and AKDOT\&PF requested continued monitoring of the flow and scour conditions at the bridge and assessing a proposed new channel to divert flow away from the bridge. In both areas, the USGS

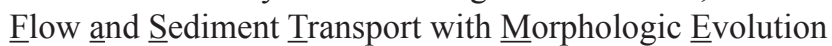
of Channels (FaSTMECH) model was applied to assess the effects of (1) raising the road grade from Mile 38-43 and (2) constructing a channel to divert flow away from Bridge 339.

\section{Physical Setting}

The study area includes the area from the Copper River at the Million Dollar Bridge to approximately $1 \mathrm{mi}$ south of the Copper River Highway (fig. 2). As the Copper River flows past Childs Glacier, the flood plain expands to more than three times its width near the terminus of Childs Glacier. In the northern part of the study area, near the Million Dollar Bridge, deposits are primarily glacial-gravel and boulders with diameters as large as $3 \mathrm{ft}$, whereas in the southern part of the alluvial plain, downstream of Childs Glacier, deposits are fine-grained alluvium. Many braided and shifting channels dissect the alluvial plain. The USGS operates a stream gage at the Million Dollar Bridge (USGS gaging station 15214000). Annual mean flow for the period of record (1988-2011) is $63,280 \mathrm{ft}^{3} / \mathrm{s}$. The highest recorded daily mean flow is $433,000 \mathrm{ft}^{3} / \mathrm{s}$, and the lowest recorded daily mean flow is $6,500 \mathrm{ft}^{3} / \mathrm{s}$. 


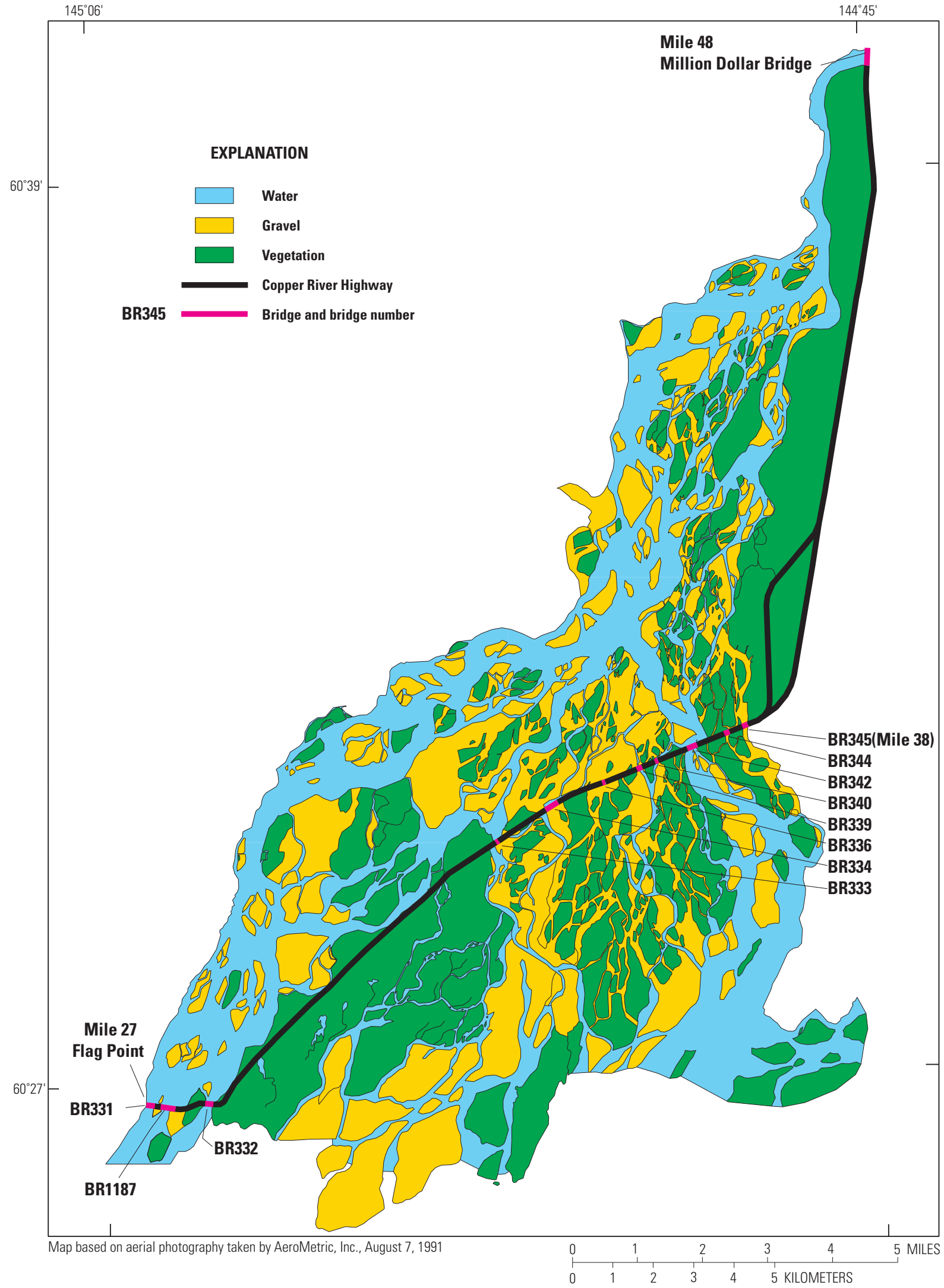

Figure 3. Locations of bridges along the Copper River Highway, Alaska. 


\section{Methods of Data Collection and Analysis}

To assess the constantly changing conditions at Bridge 339, a series of flow measurements were made in 2010 and 2011 at Bridge 339 and at other bridges along the Copper River Highway. For each flow measurement, the percentage of total flow (represented by the flow measured at the Million Dollar Bridge) was computed and plotted over time. If the percentage of flow increased, a channel change would be assumed.

To provide the most up-to-date detailed elevation data of the study area, new Light Detection and Ranging (LiDAR) data of the study area were collected November 7-10, 2009, during low flow $\left(16,800 \mathrm{ft}^{3} / \mathrm{s}\right)$ at the Million Dollar Bridge (USGS gaging station 15214000). Most of the area was bare earth at the time of the LiDAR data collection and only the main channels were present. To assess recent channel changes, aerial photographs of the study area were obtained on October 4, 2011, during another low-flow period $\left(27,100 \mathrm{ft}^{3} / \mathrm{s}\right)$, and compared with previous photography collected in October 2006 and the LiDAR data collected in 2009 .

Input data for FaSTMECH consisted of ground elevation from the LiDAR data set, water-surface elevations, and flow. Water-surface elevation and flow data were available from the stream gage at the Million Dollar Bridge and at the bridges from Mile 27 to Mile 38. Water-surface elevations also were obtained from the LiDAR data. Other input variables to FaSTMECH, such as the drag coefficient and lateral eddy viscosity, were taken from previous studies (Brabets and Conaway, 2009, 2010).

\section{Hydrology at Bridge 339}

The flow conditions at Bridge 339 from June 2001 through October 2010 have been documented in previous reports (Brabets and Conaway, 2009; Conaway and Brabets, 2011). Bridge 339 was designed for a maximum flow of $17,500 \mathrm{ft}^{3} / \mathrm{s}$, and until 2001, this bridge design was adequate and no problems occurred with the bridge or the approach to the bridge. In 2001, a channel shift upstream of Bridge 339 resulted in reduced flow toward the Flag Point bridges (BR331, BR1187, and BR332; fig. 3) and increased flow toward Bridge 339. Since 2001, the increased flow at Bridge 339 during the open-water season has exceeded the design for maximum flow.
The conditions at Bridge 339 were further compounded by another channel change that occurred during the flood of October 2006. After the flood, the main channel of the Copper River began to migrate westward away from Bridge 342 and toward Bridge 339 (fig. 4). However, the gradual effects of the channel change were not immediately evident. Flow conditions were similar in 2007 and 2008, but in 2009, the channel shift was more evident as documented by the 2009 LiDAR data.

From June to August 2010 during the open water period, flow at Bridge 339 continually exceeded 45,000 ft $3 / \mathrm{s}$ (table 1). The percentage of total flow of the Copper River (total flow as measured at the Million Dollar Bridge) that passes through Bridge 339 has increased significantly since 2010 (ig. 5). By June 2010, the misalignment of flow direction to the bridge opening caused severe erosion around the right-bank abutment that required emergency placement of riprap to protect the western approach to the bridge. The streambed scoured to a level at which minimum pile embedment criterion for lateral stability was barely satisfied for piers 2 and 3 . For the next 6 weeks, bed elevations remained at $1-4 \mathrm{ft}$ above the threshold for bridge closure. Biweekly channel soundings collected during the remainder of summer 2010 indicated that bed elevations did not drop below the threshold for bridge closure.

Table 1. Flow measurements and percentage of total flow at Bridge 339, Bridge 342, and the Million Dollar Bridge, Copper River Highway, Alaska, 2010-11.

[Bridge locations are shown in figure 3. Flow is in cubic feet per second. Total flow represents flow measured at the Million Dollar Bridge]

\begin{tabular}{|c|c|c|c|c|c|}
\hline \multirow{2}{*}{ Date } & \multicolumn{2}{|c|}{ Bridge 339} & \multicolumn{2}{|c|}{ Bridge 342} & \multirow{2}{*}{$\begin{array}{c}\begin{array}{c}\text { Million } \\
\text { Dollar Bridge }\end{array} \\
\text { Flow }\end{array}$} \\
\hline & Flow & $\begin{array}{l}\text { Total flow } \\
\text { (percent) }\end{array}$ & Flow & $\begin{array}{l}\text { Total flow } \\
\text { (percent) }\end{array}$ & \\
\hline \multicolumn{6}{|c|}{2010} \\
\hline June 10 & 45,300 & 37 & 53,000 & 43 & 122,000 \\
\hline July 2 & 60,300 & 36 & 72,500 & 43 & 168,000 \\
\hline July 7 & 59,500 & 36 & 74,350 & 44 & 167,000 \\
\hline August 10 & 74,000 & 33 & 85,000 & 38 & 225,000 \\
\hline August 31 & ${ }^{1} 47,400$ & 40 & 42,200 & 36 & 118,000 \\
\hline September 22 & 35,700 & 48 & 28,500 & 38 & 74,400 \\
\hline \multicolumn{6}{|c|}{2011} \\
\hline June 1 & 59,700 & 42 & 50,200 & 35 & 142,000 \\
\hline July 6 & 70,000 & 47 & 48,400 & 33 & 148,000 \\
\hline July 19 & 86,500 & 41 & 62,600 & 30 & 210,000 \\
\hline August 4 & 75,000 & 42 & 53,200 & 30 & 178,000 \\
\hline August 19 & 86,000 & 66 & 22,300 & 17 & 131,000 \\
\hline September 14 & 71,200 & 90 & 5,000 & 6 & 79,400 \\
\hline
\end{tabular}

${ }^{1}$ The first time total flow at Bridge 339 exceeded total flow at Bridge 342 . 


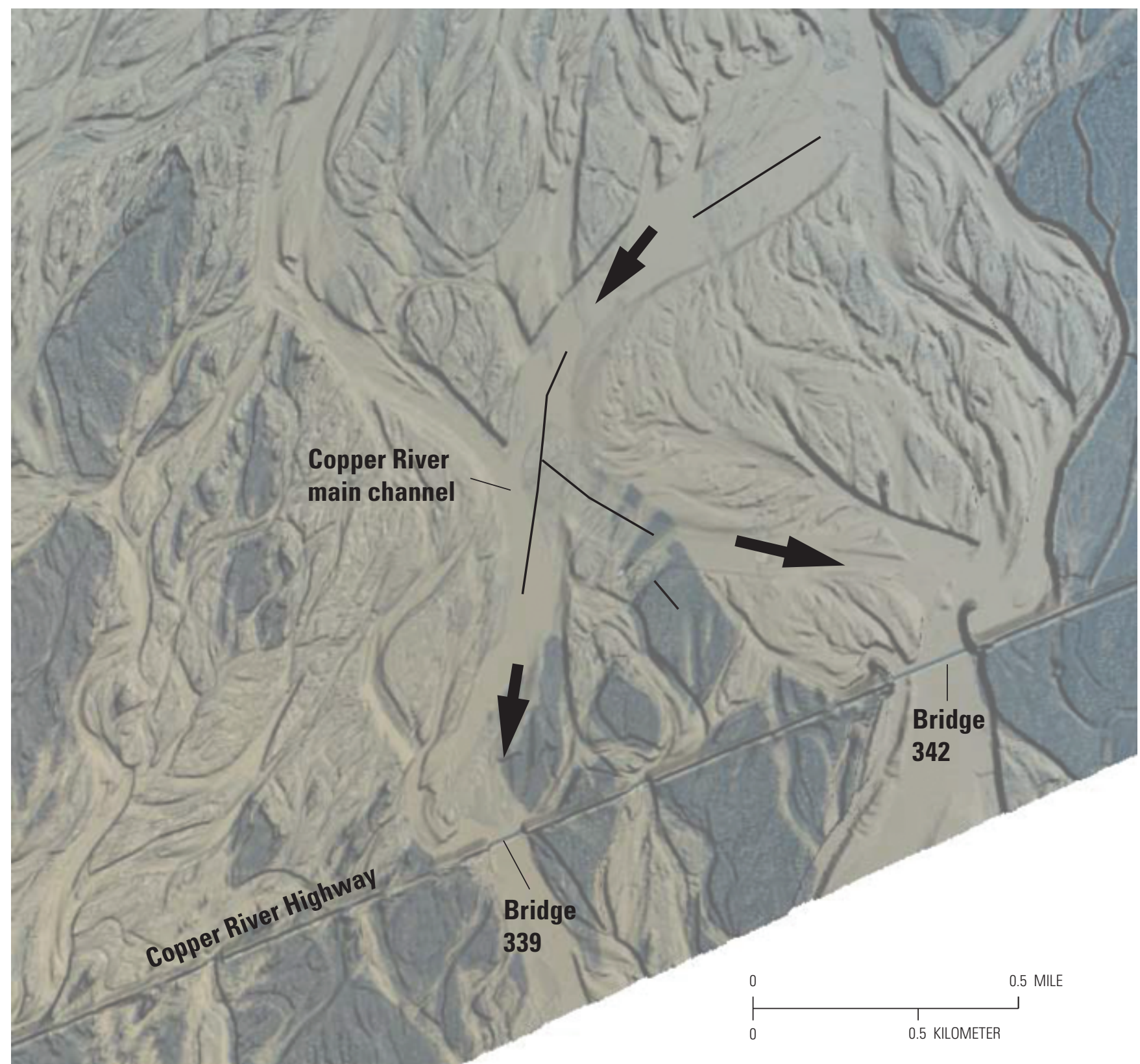

Aerial photograph taken by AeroMetric, Inc., October 15, 2006 LiDAR by AeroMetric, Inc., November 7-10, 2009

Figure 4. LiDAR data from 2009 overlaid on aerial photograph from 2006 showing channel changes at Bridge 339 and Bridge 342 , Copper River Highway, Alaska. 


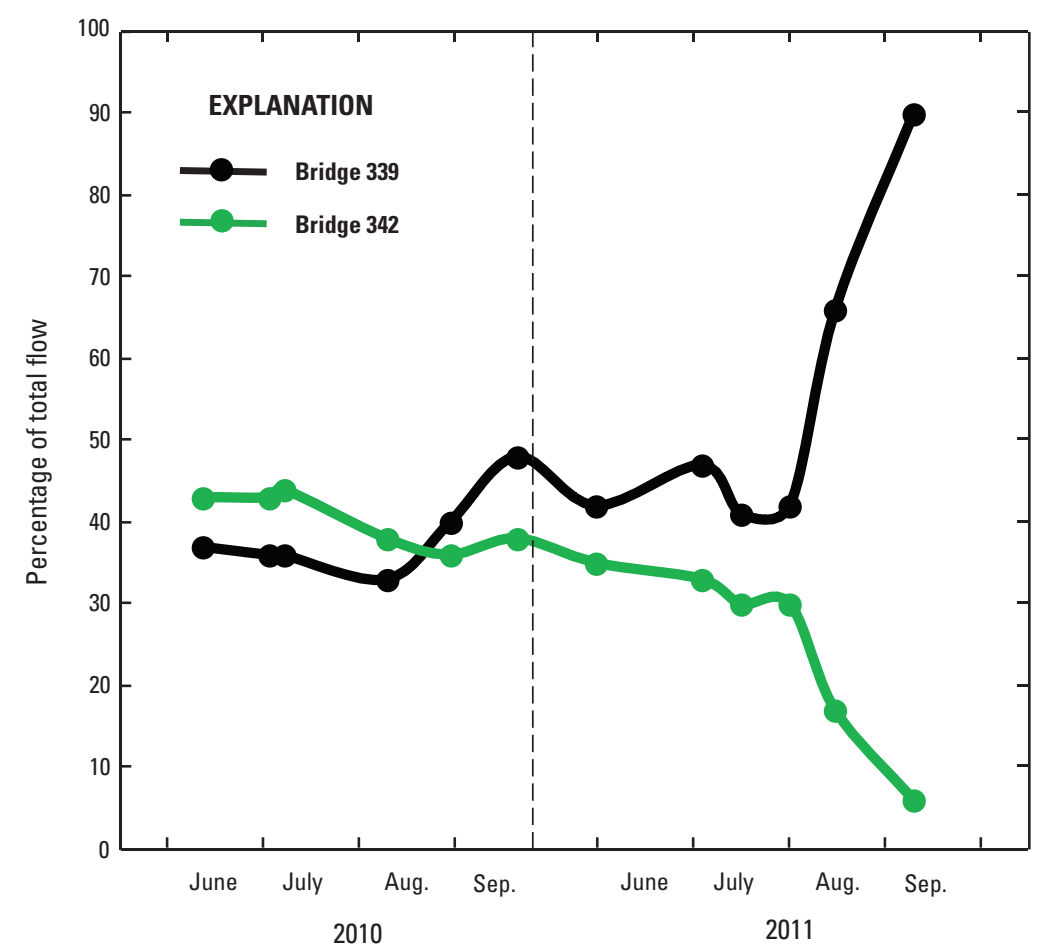

Figure 5. Percentage of total flow passing through Bridges 339 and 342 during open water period, Copper River Highway, Alaska, from June 2010 to September 2010 and 2011. Total flow as measured at the Million Dollar Bridge.

The August 31, 2010, flow measurement was significant because it documented the first time that flow through Bridge 339 was higher than the flow through Bridge 342. The hydrograph from the Million Dollar Bridge (fig. 6) shows that the measurement was made during a recession period beginning August 6, 2010. From August 6 to August 31, flow at the Million Dollar Bridge generally decreased from 276,000 to $118,000 \mathrm{ft}^{3} / \mathrm{s}$. During this period, water likely flowed toward Bridge 342, and the channel filled in; the channel leading toward Bridge 339 became the dominant channel. Since then, measured flows through Bridge 339 have exceeded measured flows through Bridge 342 (figs. 4 and $\underline{5}$ ).

During the first part of the open water period in 2011, the measured flow through Bridge 339 was about 40 percent of the total flow of the Copper River until about mid-August (table 1, fig. 5). From August 4 to August 15, flow of the Copper River measured at the gaging station at the Million Dollar Bridge decreased from $178,000 \mathrm{ft}^{3} / \mathrm{s}$ to $121,000 \mathrm{ft}^{3} / \mathrm{s}$. During this recession period, additional filling of the channel leading to Bridge 342 likely occurred, causing more water to flow into the channel leading to Bridge 339. Measurements made on August 19 and September 14 indicated that flows through Bridge 339 were 66 and 90 percent of the total flow, respectively. As a result of these flows, as much as $50 \mathrm{ft}$ of scour was measured near piers 4 and 5 of Bridge 339 (fig. 7), severely undermining the capacity of the piers to absorb lateral or vertical loads. Because of these conditions, AKDOT\&PF closed the Copper River Highway at Bridge 339 on August 19, 2011. 


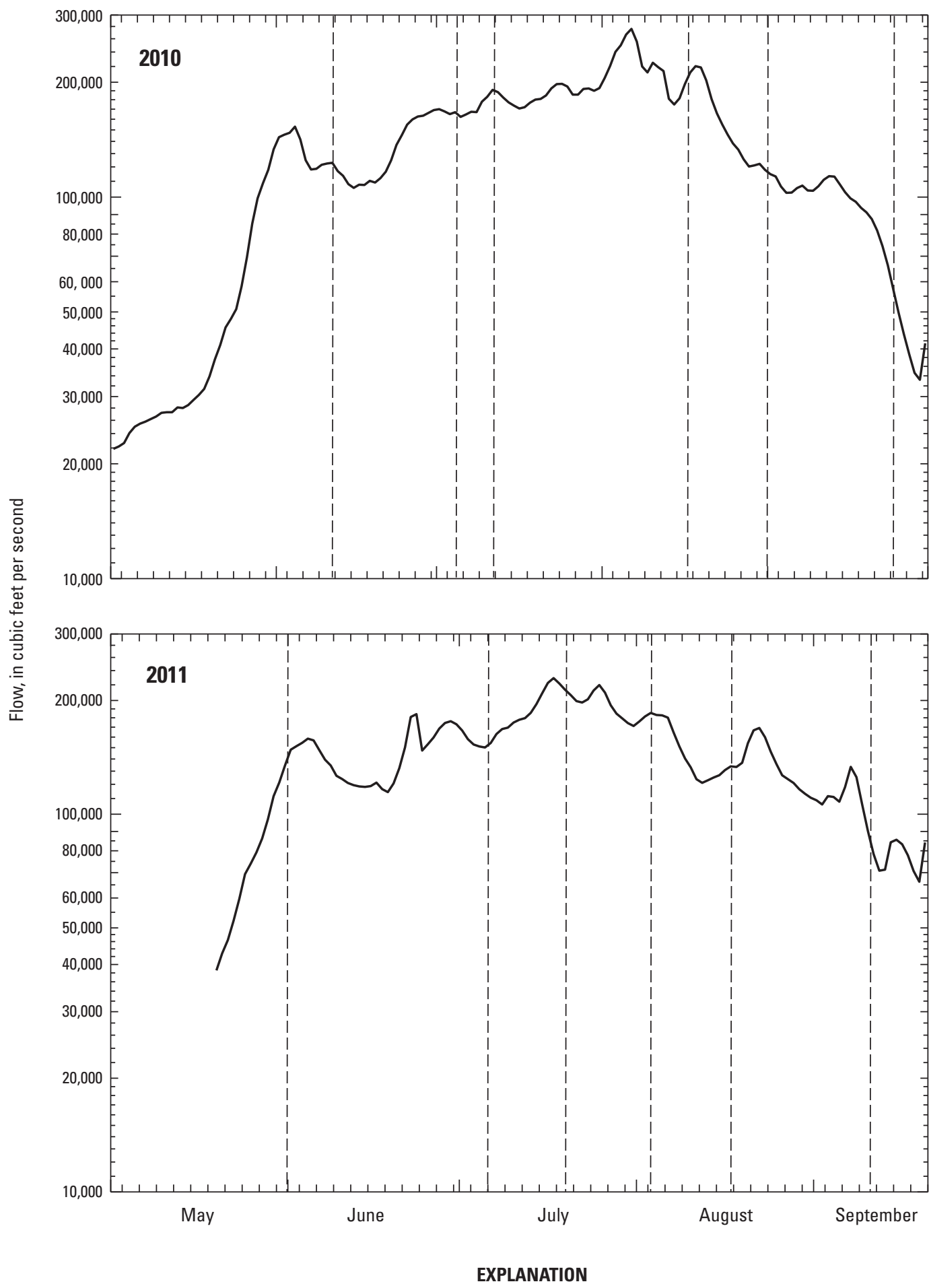

- - - - - Measurement and sounding at Bridge 339

Flow at Copper River at Million Dollar Bridge

Figure 6. Flow at the Copper River at the Million Dollar Bridge, and measurements and soundings at Bridge 339, Copper River Highway, Alaska, May 1 to September 30, 2010, and 2011. 


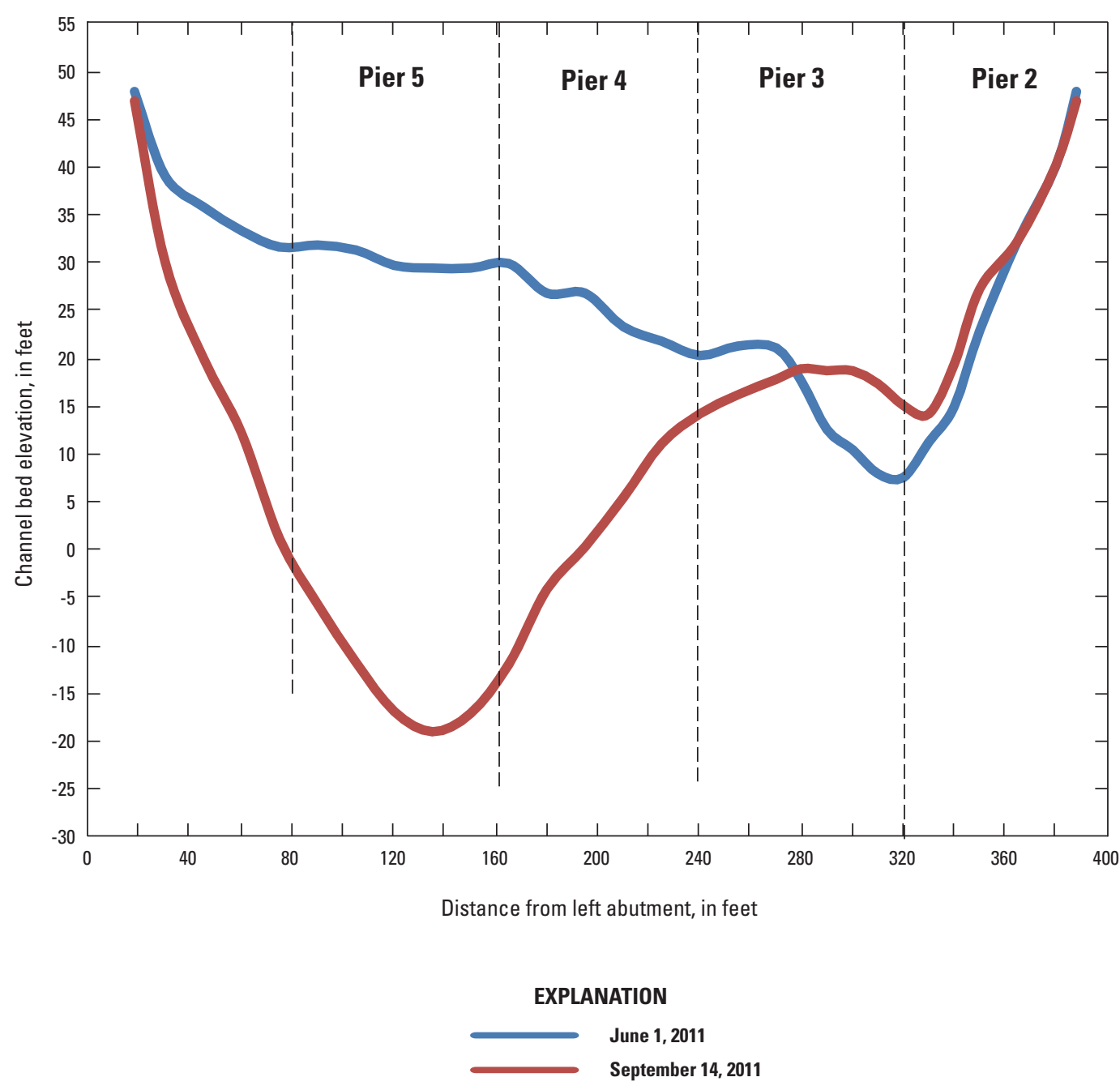

Figure 7. Scour at Bridge 339, Copper River Highway, Alaska, June 1 and September 14, 2011.

Comparison of the LiDAR data set from 2009 (fig. 8A) and the aerial photograph taken in 2011 (fig. $8 B$ ) shows the main channel reoccupying an abandoned channel upstream of Bridges 339 and 342. This channel change resulted in a pronounced bend in the channel that changed the direction of flow to the southwest, away from Bridge 342 (fig. 8A). Downstream of this change, the 2009 LiDAR data show the channel toward Bridge 339 splitting equally, one channel directed back toward Bridge 342 and one channel toward Bridge 339. The 2011 photograph (fig. 8B) shows the channel toward Bridge 342 filled in, which verifies the pattern determined with the flow measurements and indicates that flow likely will increase toward Bridge 339 in the future. 
A.

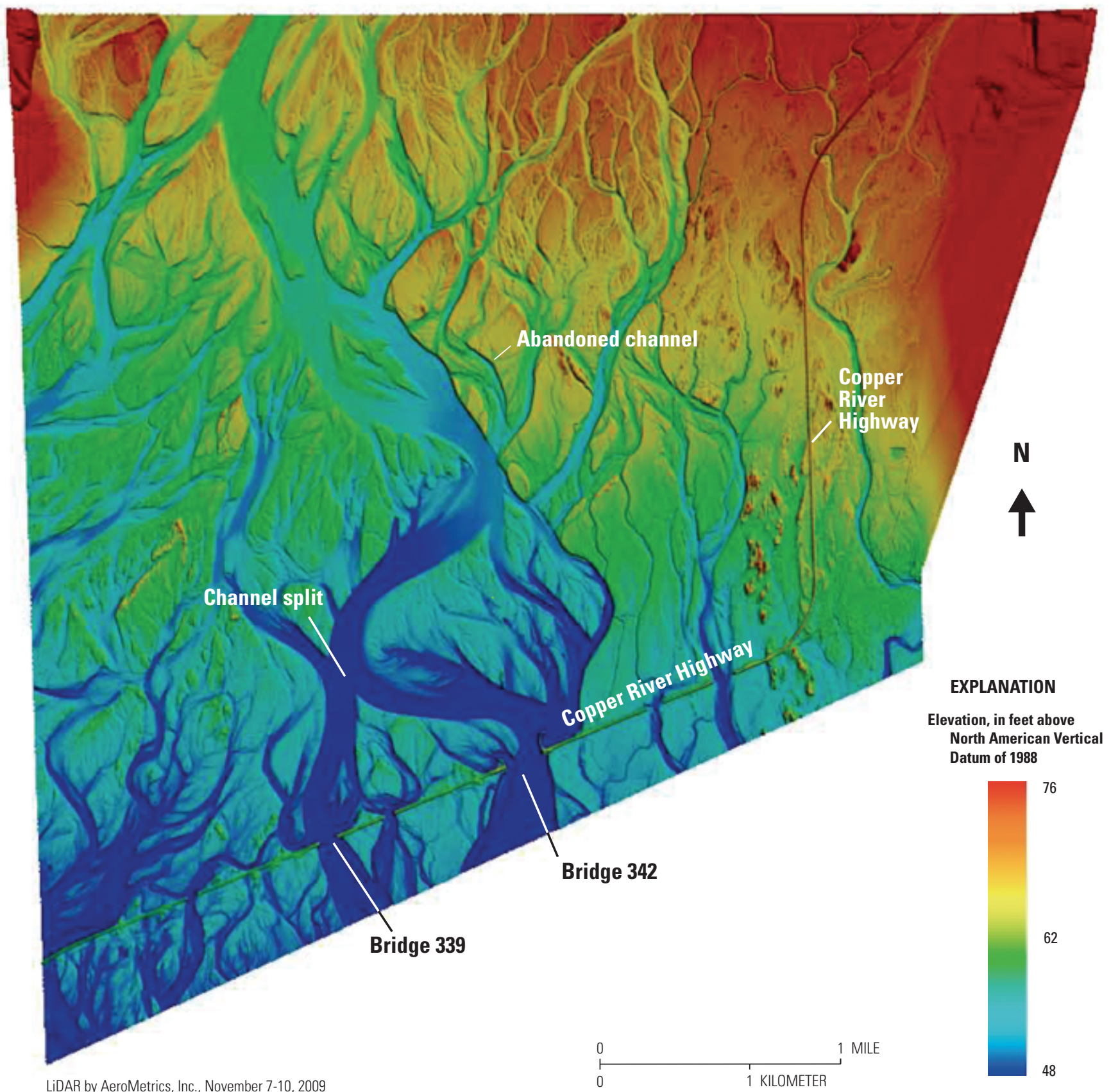

Figure 8. (A) LiDAR data from November 7-10, 2009, and (B) aerial photograph from October 4, 2011, at Bridges 339 and 342, Copper River Highway, Alaska. 
B.

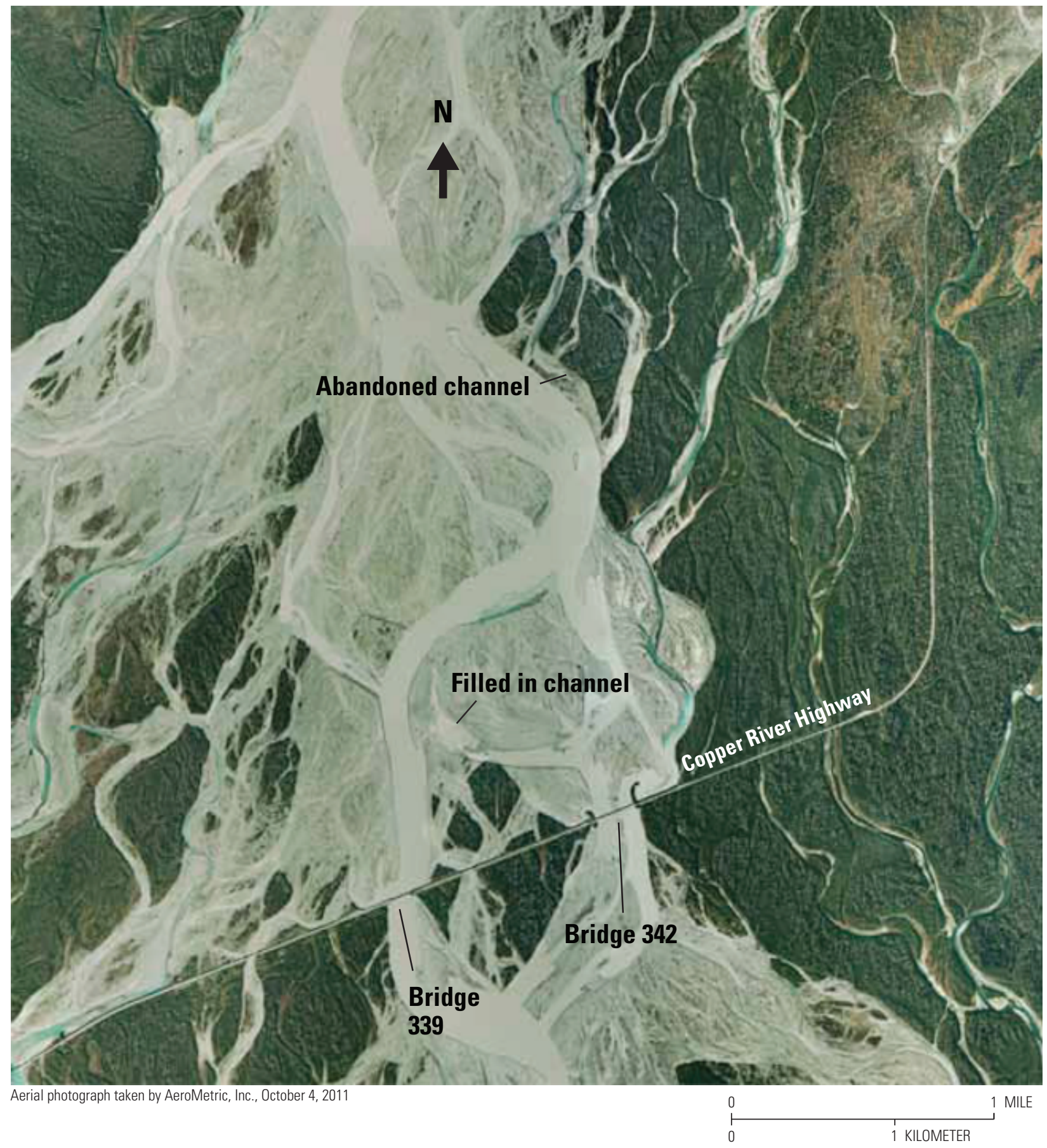

Figure 8.-Continued 


\section{FaSTMECH Modeling System}

FaSTMECH is a computational model developed by the USGS (Nelson and McDonald, 1997) that includes a 2-dimensional, vertically averaged model and a sub-model that calculates vertical distribution of the primary velocity and the secondary flow about the vertically averaged flow. This 2.5-dimensional approach adequately simulated the velocity field and bed shear stress, without the complexity of a fully 3 -dimensional model. The model is embedded within a single graphical user interface (GUI) as part of the International River Interface Cooperative (iRIC) (Nelson and others, 2010), so that other models can be made available to users without requiring them to learn new pre- and post-processing tools. Previously, FaSTMECH was part of the USGS MultiDimensional Surface Water Modeling System (MD_SWMS; McDonald and others, 2001, 2005), which since has been merged into iRIC.

Minimum data requirements for the model include a digital elevation model (DEM) of the area of interest, channel geometry, flow at the upstream boundary, and water-surface elevation at the downstream boundary. The physical assumptions of the model are that flow is steady, incompressible, and hydrostatic (vertical accelerations are neglected), and that turbulence is accounted for adequately by relating Reynolds stresses to shear using an isotropic eddy viscosity (Nelson and others, 2003).

\section{Model Calibration}

For this study, the spatially uniform drag coefficient was adjusted until the simulated water-surface slope through the model reach reproduced as closely as possible the measured water surface. Physically, this process is equivalent to ensuring that the roughness value used in FaSTMECH accurately simulates the head loss in the channel over long reaches. Because the downstream water-surface elevation was set as a model boundary condition, this process ensured that the reach-averaged water-surface slope simulated by FaSTMECH matched the measured water surface.

FaSTMECH incorporates a lateral eddy viscosity (LEV) to represent lateral momentum exchange due to turbulence or other variability that is not generated at the channel bed (Nelson and others, 2003). The model LEV parameter is computed using the following equation:

$$
\mathrm{LEV}=0.01 * u_{\mathrm{ave}} * y_{\mathrm{ave}},
$$

where

LEV is lateral eddy viscosity coefficient, in feet squared per second,

$u_{\text {ave }}$ is average velocity, in feet per second, and

$y_{\text {ave }}$ is average depth, in feet.
The LEV value used was based on previous modeling (Brabets and Conaway, 2009) and was applied uniformly throughout the modeled reach for each calibration streamflow. Similar to the drag coefficient, the LEV was adjusted within reasonable limits during the calibration process to reproduce as closely as possible the measured water-surface elevation.

As an additional check of the accuracy of the calibration, model convergence is evaluated by comparing the predicted model flow to the measured specified flow for a selected cross section. For this study, FaSTMECH was run for 5,000 iterations. If the percent deviation from the normalized flow was within plus or minus 3 percent, the convergence was considered acceptable. If the convergence was greater than plus or minus 3 percent, the values for the drag coefficient and LEV were checked to make sure they were within reasonable limits. The relaxation, or startup, parameters E (water-surface elevation), U (velocity), and A (global slope) were adjusted so FaSTMECH could start its computational routines. For this study, model calibration was considered acceptable if the predicted compared with measured water-surface elevations were within plus or minus $1.5 \mathrm{ft}$, and convergence was within plus or minus 3 percent.

\section{Computational Grid and Boundary Conditions}

The computational grid used in FaSTMECH is a curvilinear orthogonal coordinate system with a user-defined centerline, defined interactively to approximate the mean flow streamline of the modeled reach (Nelson and others, 2003). The topography is mapped to the coordinates of the computational grid through a nearest-neighbor method weighted by inverse distance. Model coordinates (easting and northing) are based on the North American Datum of 1983 (NAD 83), Alaska Universal Transverse Mercator projection, and elevations are based on the North American Vertical Datum 1988 (NAVD 88).

Brabets and Conaway (2009) documented the recent effects the river has had on the Copper River Highway from Mile 38 to Mile 43. In brief, the high flows in 2001 created a new channel of the Copper River that cut through a low-lying section of land adjacent to the highway and reoccupied an old channel, which inundated the area adjacent to this section of the highway. Part of the highway washed out and several culverts were placed along the highway to prevent reflooding. One of the main channels of the Copper River approached to within $100 \mathrm{ft}$ of the Copper River Highway, but at the time of the 2009 LiDAR, the channel had migrated away from the highway (fig. 9). However, at high flows, the highway is still subject to flooding at this location. For example, in September 2007, the highway was almost overtopped at a flow of $271,000 \mathrm{ft}^{3} / \mathrm{s}$. To avoid potential overtopping along Mile 38-43, AKDOT\&PF proposed to raise the road grade by $5 \mathrm{ft}$ in this stretch of the highway. To determine the effectiveness of raising the road grade, two measured flows, 


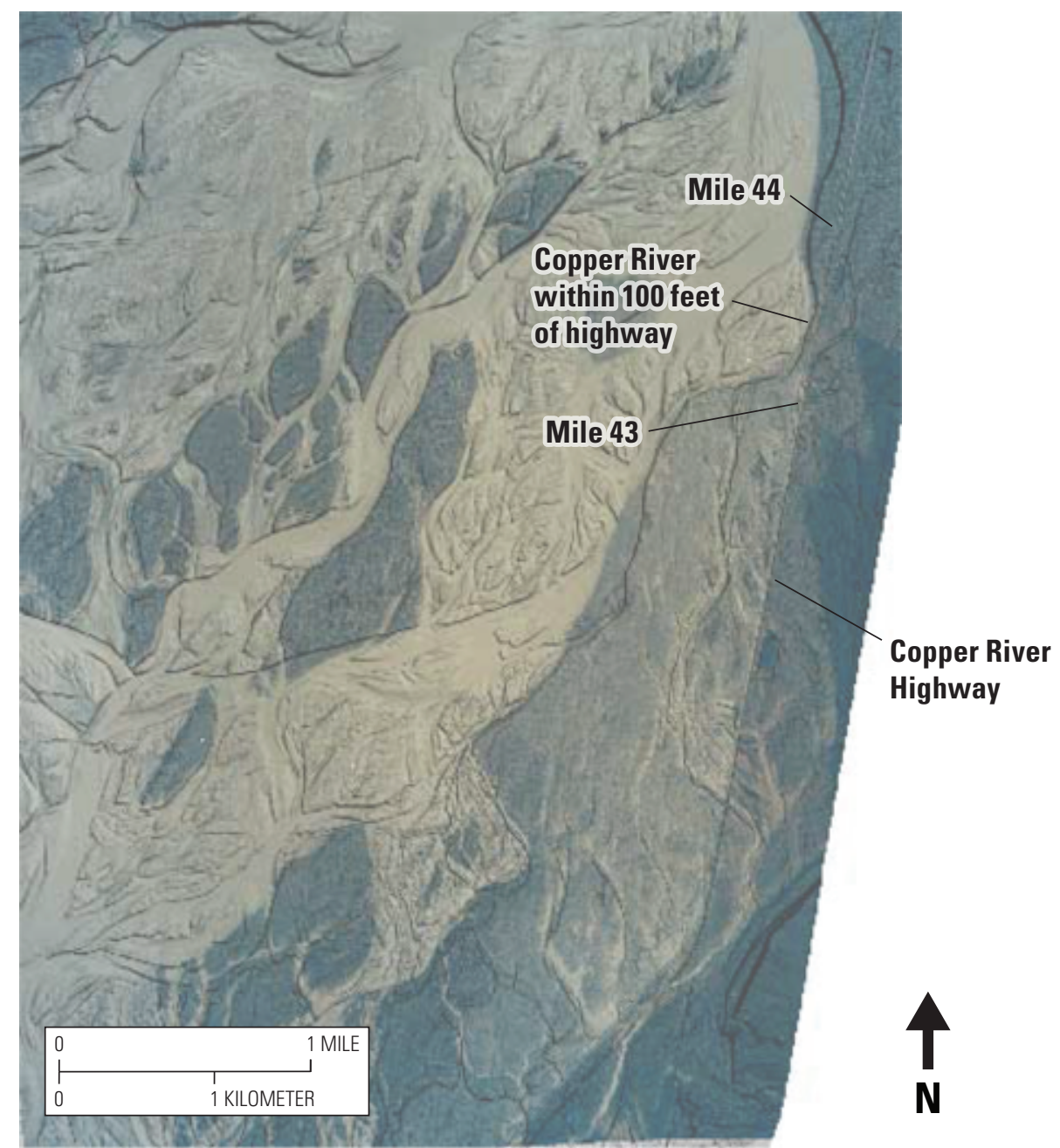

Photograph taken by AeroMetric, Inc. October 15, 2006 LiDAR by AeroMetric, Inc., November 7-10, 2009

Figure 9. LiDAR data from 2009 overlaid on aerial photographs from 2006 near the Mile 38-43 area, Copper River Highway, Alaska.

$116,000 \mathrm{ft}^{3} / \mathrm{s}$ and $174,000 \mathrm{ft}^{3} / \mathrm{s}$, and an additional large flow, $400,000 \mathrm{ft}^{3} / \mathrm{s}$ were simulated. The highest flow represents an annual exceedance probability (AEP) of 2 percent or an occurrence of approximately once in 50-years. This flow was based on USGS flood frequency equations developed by Curran and others (2003) and was used to determine if a flow of this magnitude would overtop the Copper River Highway after the road grade was raised $5 \mathrm{ft}$. Additionally, all simulated flow scenarios were based on removal of the culverts along Mile 38-43.

Although the Mile 38-43 area is about $15 \mathrm{mi}^{2}$, the computational grid covers a much larger area of about $40 \mathrm{mi}^{2}$ (fig. 10). This grid size was selected because it represents the entire flow path of the Copper River and allows the streamflow from the gaging station at the Million Dollar Bridge to be used as an upstream boundary condition. For this area, the digital elevation model (DEM) solely consists of the 2009 LiDAR data. The channels along Mile 38-43 at the time of the LiDAR data collection were completely dry. Given the flow and water-surface elevation at the time of LiDAR data collection $\left(16,800 \mathrm{ft}^{3} / \mathrm{s}, 125.83 \mathrm{ft}\right.$, respectively), the few main channels of the Copper River were assumed to be $3 \mathrm{ft}$ deep and a bed-elevation was constructed $3 \mathrm{ft}$ below the water-surface elevation. This assumption was presumed to have only a relatively minor effect on the model output because FaSTMECH was used at flows and water-surface elevations of $116,000 \mathrm{ft}^{3} / \mathrm{s}(135.70 \mathrm{ft}), 174,000 \mathrm{ft}^{3} / \mathrm{s}(139.40 \mathrm{ft})$, and $400,000 \mathrm{ft}^{3} / \mathrm{s}(150.00 \mathrm{ft})$. At these flows and elevations, much of the flood plain is inundated and the percentage of the flood plain that consists of the main channels is relatively small. The computational grid for the Mile 38-43 area was $42,750 \mathrm{ft}$ long (511 nodes) in the downstream direction and $21,325 \mathrm{ft}$ wide ( 311 nodes) in the cross-section direction, forming an approximately 8.1 by $4.0 \mathrm{mi}$ grid consisting of 135,200 cells spaced every $82 \mathrm{ft}$ in the downstream and cross-stream directions. 


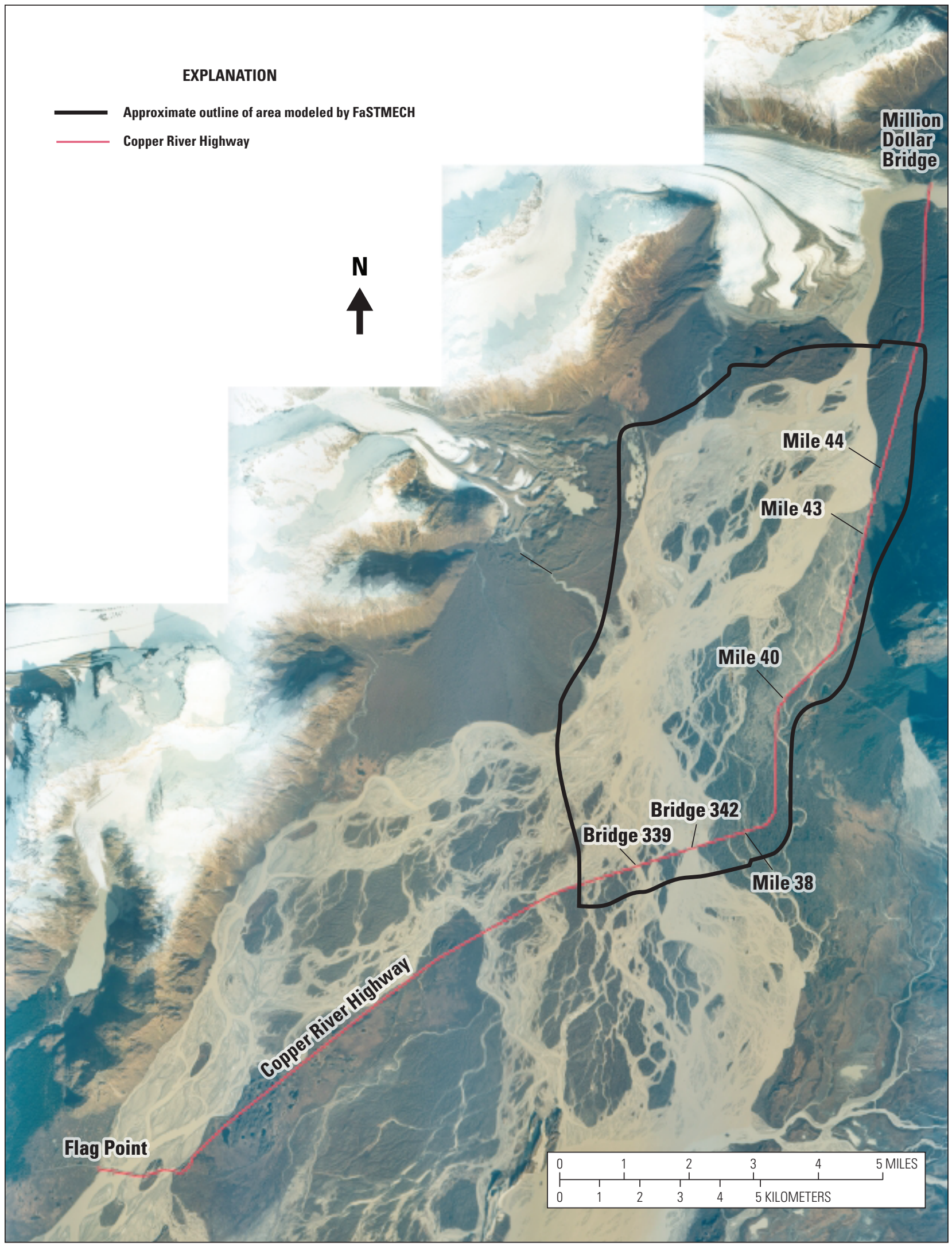

Aerial photograph taken by AeroMetric, Inc., October 15, 2006

Figure 10. Approximate outline of computational grid for FaSTMECH, Mile 38-43, Copper River Highway, Alaska. 
The boundary conditions for Mile 38-43 used during model calibration included: (1) streamflow and watersurface elevations at the upstream model boundary, and (2) water-surface elevations at the downstream model boundary. Water-surface elevation at the upstream boundary was computed using the elevation at the Million Dollar Bridge with an assumed constant water-surface slope downstream to the upstream boundary. Flows used for the upstream boundary were measured from the stream gage at the Million Dollar Bridge. The water-surface elevations at the downstream boundary were based on measurements taken from Bridges 339 and 342. For the modeled 400,000 ft $3 / \mathrm{s}$ flow, water-surface elevations were estimated at the downstream boundary from water-surface elevation data collected during the September 1995 flood (peak flow 415,000 $\mathrm{ft}^{3} / \mathrm{s}$ ) and the October 2006 flood (peak flow 444,000 ft $3 / \mathrm{s}$ ).

Based on the analysis of the 2010 and 2011 flow measurements and the 2011 aerial photography, additional flow likely will be directed toward Bridge 339 in the future. However, to repair piers 4 and 5 and the left abutment, or lengthen the bridge (if necessary) in safe working conditons, flow through Bridge 339 would need to be lowered to near the bridge design flow of $17,500 \mathrm{ft}^{3} / \mathrm{s}$. Construction of a temporary channel upstream of Bridge 339 that intersects the main channel of the Copper River could divert flow away from Bridge 339 and toward Bridge 334, a 1,200 ft long bridge. (fig. 11). Given that the highest flow measured at Bridge 339 is $86,500 \mathrm{ft}^{3} / \mathrm{s}$, the diversion channel would have to be large enough to convey this amount of flow. The initial design of the simulated channel was about 3,000 ft long, $250 \mathrm{ft}$ wide, and $10 \mathrm{ft}$ deep. All excavated material from constructing the diversion channel would be placed on the south side of the channel to form a berm to prevent flow from moving southward and affecting the highway. FaSTMECH was then used to determine the effects of various flows up to $100,000 \mathrm{ft}^{3} / \mathrm{s}$.

The computational grid for the Bridge 339 area begins about 4,000 $\mathrm{ft}$ upstream of the bridge and includes the main channel of the Copper River before it splits; the grid trends in a southwest direction toward Bridge 334 (fig. 11). The grid area was selected so a channel and berm that would divert flow away from Bridge 339 could be placed within the grid. The computational grid was 3,280 ft long (91 nodes) in the downstream direction and 3,280 ft wide (91 nodes) in the cross-section direction, forming an approximately 0.6 by $0.6 \mathrm{mi}$ grid consisting of 40,000 cells spaced every
$16 \mathrm{ft}$ in the downstream and cross-stream directions. Similar to the Mile 38-43 area, the LiDAR data collected in 2009 was used as the DEM. Water-surface elevations were measured at bridges and determined from the LiDAR data for the upper and lower boundaries of the computational grid.

\section{Results of Simulations-Mile 38-43}

At the Mile 38-43 area, the first two scenarios (flows of $116,000 \mathrm{ft}^{3} / \mathrm{s}$ and $174,000 \mathrm{ft}^{3} / \mathrm{s}$ ) used known water-surface elevation and flow data that were collected in the study area. Modeling these moderate flows with FaSTMECH helped determine the values of several input parameters, such as roughness and LEV, used for the high flow scenarios (table 2). The model simulation results of the first two scenarios matched well with the measured water-surface elevations and inundation areas (figs. 12-13). FaSTMECH indicated that the Copper River Highway would not be overtopped, but that there would be ponding near Mile 38 or Bridge 345, and that as flows increased, larger areas would be inundated. The conditions simulated by FaSTMECH matched those observed in the field. Because FaSTMECH results were reasonable, the input parameters were not changed for the third scenario.

For the third scenario (400,000 $\mathrm{ft}^{3} / \mathrm{s}, 2$ percent AEP flow), the model simulation results indicate that much, if not all, of the area would be flooded (fig. 14). This result is reasonable because field observations from the floods of 1995 and 2006 noted that much of the area was inundated. Based on the simulation, the water-surface elevation would range from $59 \mathrm{ft}$ at Mile 38 to about $108 \mathrm{ft}$ at Mile 43. Raising the grade of Copper River Highway by $5 \mathrm{ft}$ would increase the elevation of the road from $71 \mathrm{ft}$ at Mile 38 to about $110 \mathrm{ft}$ at Mile 43 . Thus, the highway would not be overtopped by the 2 percent AEP flow.

Table 2. Input values for flow scenarios in FaSTMECH for Mile 38-43 of Copper River Highway, Alaska.

[LEV: Lateral Eddy Viscosity. ER: Water surface relaxation parameter. UR: Velocity relaxation parameter. AR: Reach average slope relaxation parameter. Abbreviations: $\mathrm{ft}^{3} / \mathrm{s}$, cubic foot per second; $\mathrm{ft}$, foot; $\mathrm{ft}^{2} / \mathrm{s}$, foot squared per second]

\begin{tabular}{|c|c|c|c|c|c|c|c|}
\hline \multirow{2}{*}{$\begin{array}{l}\text { Flow } \\
\left(\mathrm{ft}^{3} / \mathrm{s}\right)\end{array}$} & \multicolumn{2}{|c|}{$\begin{array}{c}\text { Water-surface elevation } \\
\text { (ft) }\end{array}$} & \multirow{2}{*}{ Roughness } & \multirow{2}{*}{$\begin{array}{l}\text { LEV } \\
\left(\mathrm{ft}^{2} / \mathrm{s}\right)\end{array}$} & \multirow{2}{*}{ ER } & \multirow{2}{*}{ UR } & \multirow{2}{*}{ AR } \\
\hline & $\begin{array}{l}\text { Upstream } \\
\text { boundary }\end{array}$ & $\begin{array}{l}\text { Downstream } \\
\text { boundary }\end{array}$ & & & & & \\
\hline 116,000 & 121 & 53.5 & 0.02 & 0.54 & 0.017 & 0.007 & 0.007 \\
\hline 174,000 & 123 & 54.4 & 0.02 & 0.54 & 0.017 & 0.007 & 0.007 \\
\hline 400,000 & 134 & 58.7 & 0.02 & 0.54 & 0.017 & 0.007 & 0.007 \\
\hline
\end{tabular}




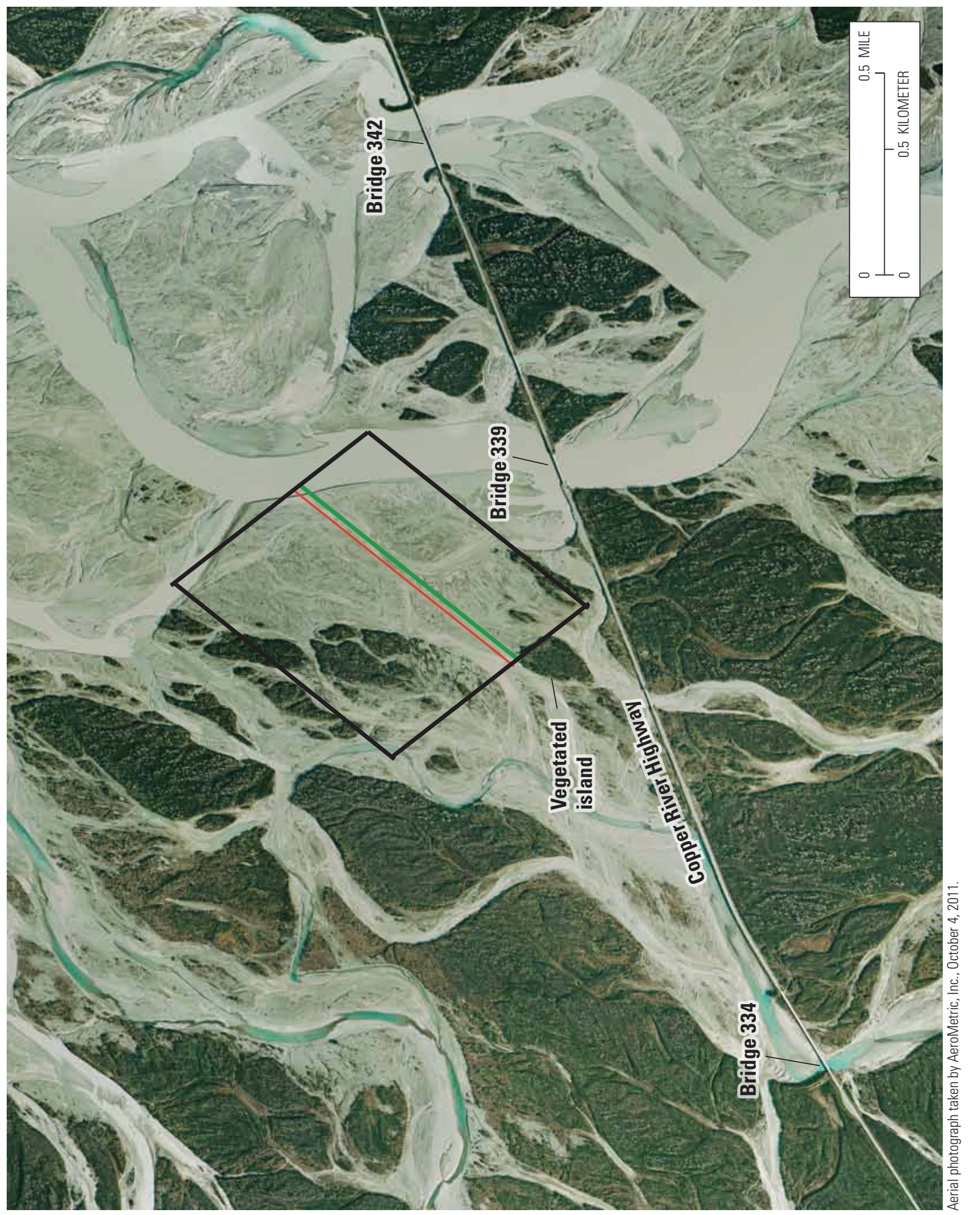

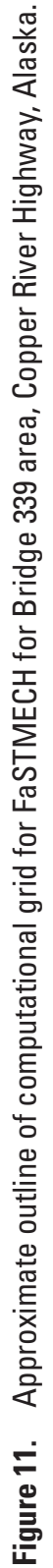

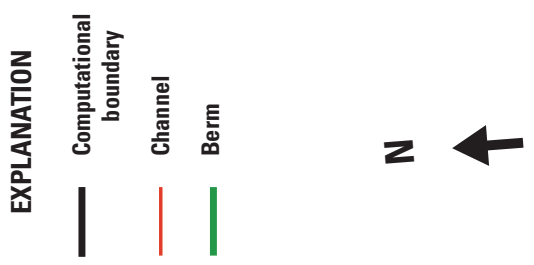




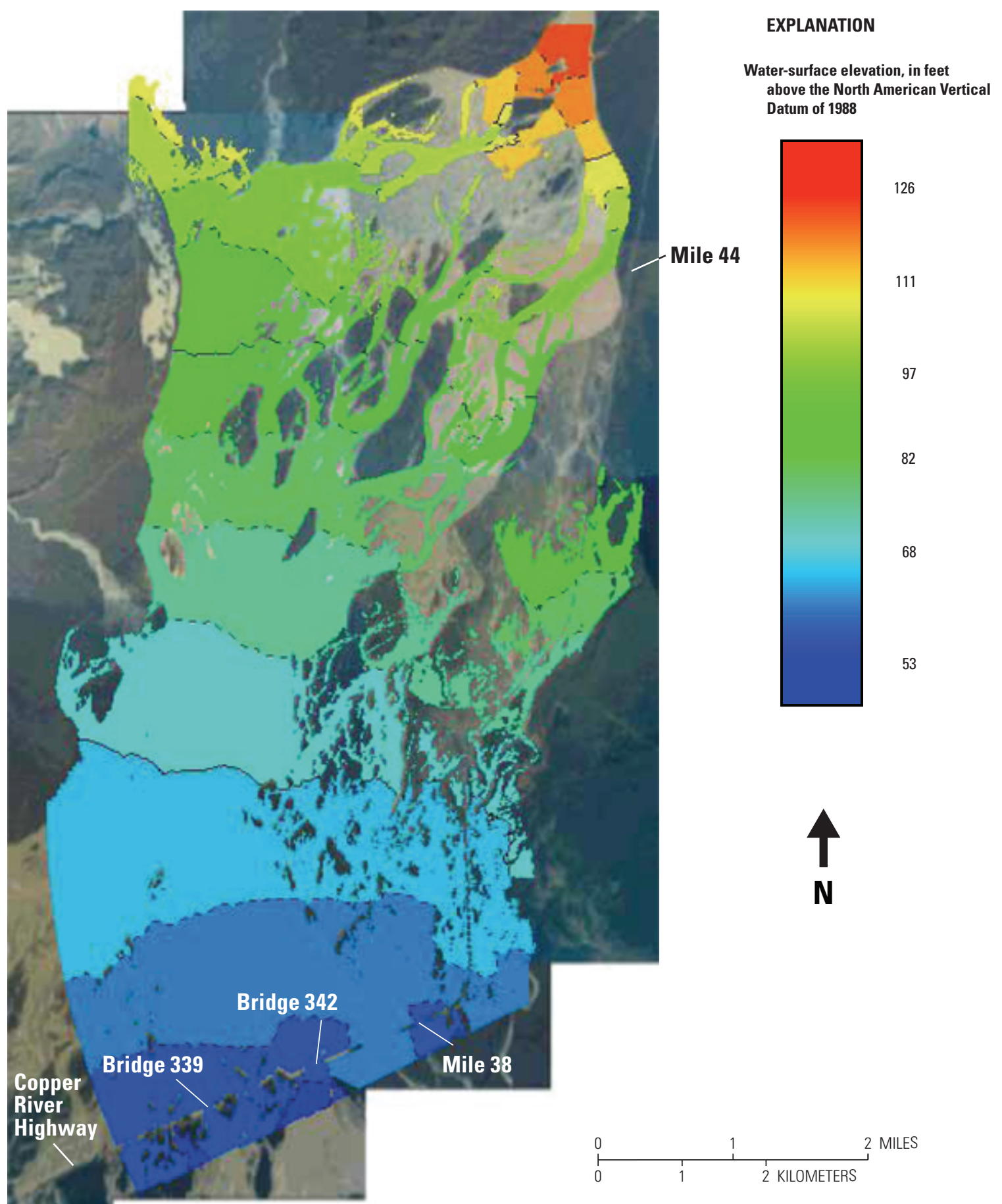

Aerial photograph taken by AeroMetric, Inc., October 15, 2006

Figure 12. Output from FaSTMECH of water-surface elevation at Mile 38-43 for a flow of 116,000 cubic feet per second, Copper River Highway, Alaska. 


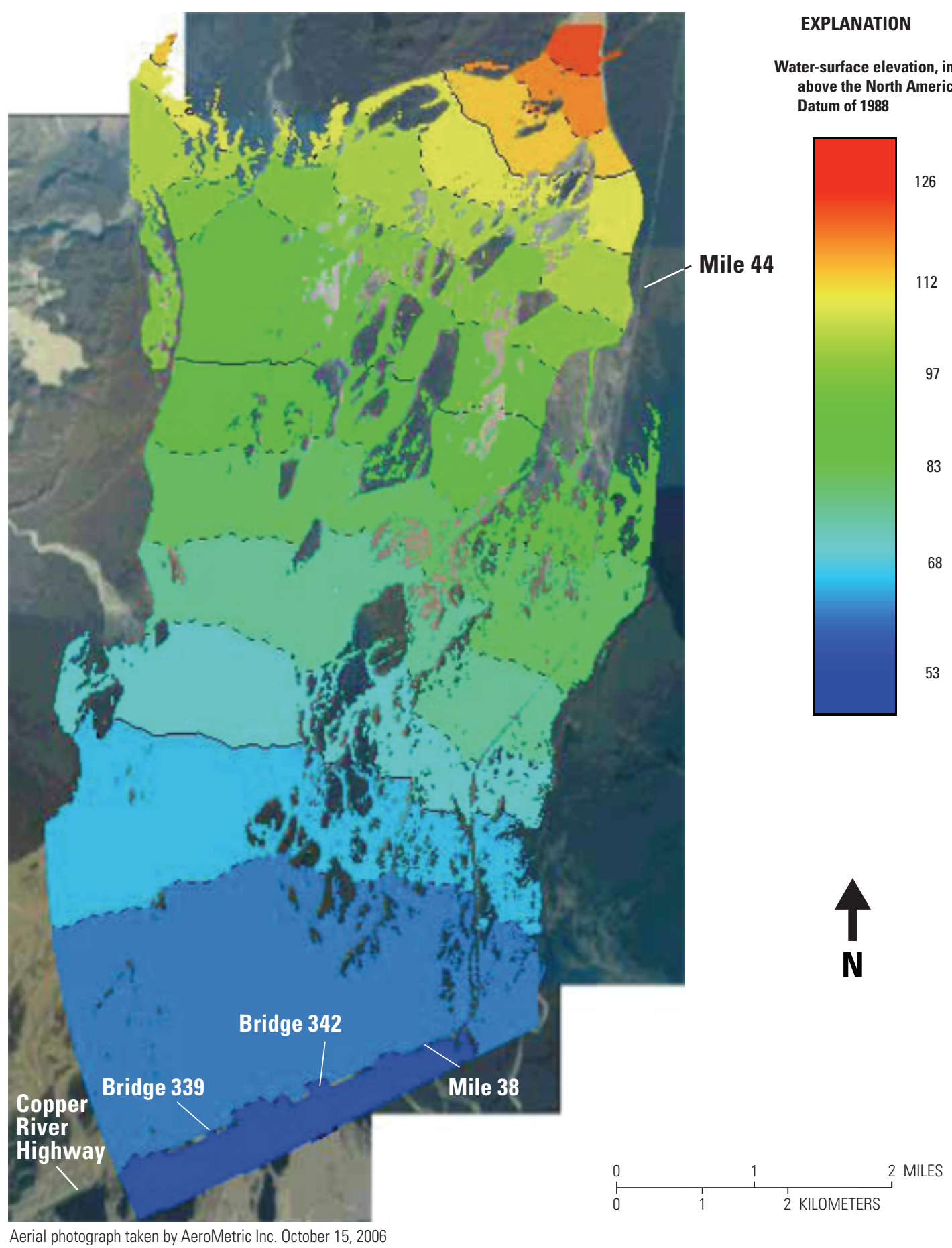

Figure 13. Output from FaSTMECH of water-surface elevation at Mile 38-43 for a flow of 174,000 cubic feet per second, Copper River Highway, Alaska. 


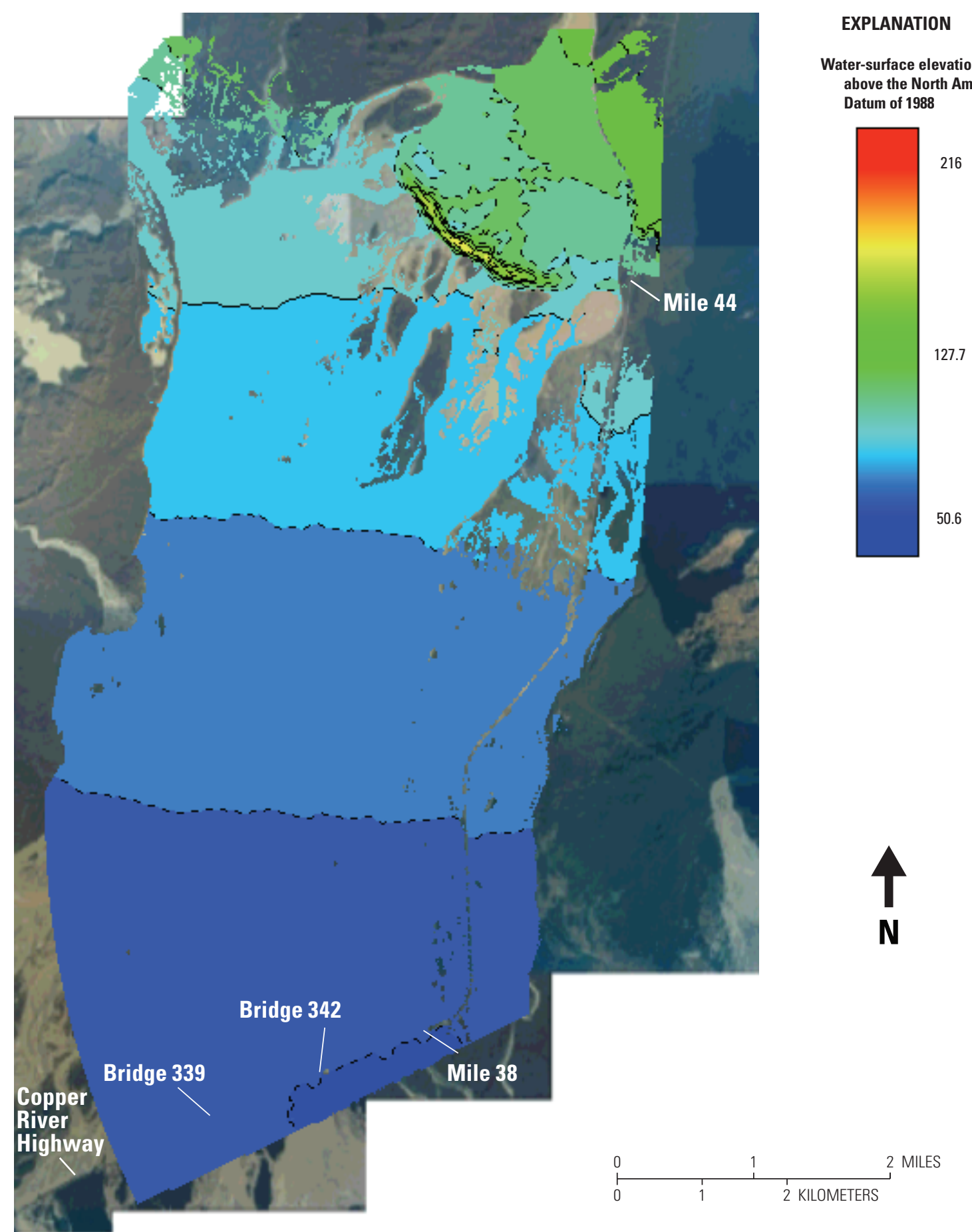

Aerial photograph taken by AeroMetric, Inc., October 15, 2006

Figure 14. Output from FaSTMECH of water-surface elevation at Mile 38-43 for a flow of 400,000 cubic feet per second, Copper River Highway, Alaska. 


\section{Results of Simulations—Bridge 339 Area}

At the Bridge 339 area, FaSTMECH was used to simulate three flows: $50,000,75,000$, and $100,000 \mathrm{ft}^{3} / \mathrm{s}$. The simulation for $50,000 \mathrm{ft}^{3} / \mathrm{s}$ was run in the 1-dimensional mode to obtain the initial upstream and downstream water-surface elevations. After these elevations were obtained, FaSTMECH was run in the 2.5-dimensional mode. Depth of water and water-surface elevation were analyzed to determine if the berm would be overtopped at the three simulated flows; water velocities computed by FaSTMECH were used to determine the shear stress at the channel bottom. The shear stress values were then compared with shear stress values summarized by Julien (1998) that determine approximate conditions for sediment mobility.

The output for all three simulated flows indicated that the deviation from the normalized flow was within plus or minus 3 percent, indicating acceptable convergence. As expected, water was deepest in the diversion channel and more surface area was inundated at $100,000 \mathrm{ft}^{3} / \mathrm{s}$ than at $50,000 \mathrm{ft}^{3} / \mathrm{s}$ (fig. 15). Numerous areas of shallow depth even at the highest flow also were noted. Simulated water-surface elevations (fig. 16) reflect the higher flows and although there are no known water-surface elevations at the downstream boundary of the modeled area, water surfaces calculated from FaSTMECH are considered reasonable. At a flow of $100,000 \mathrm{ft}^{3} / \mathrm{s}$, water-surface elevations did not exceed the height of the berm (approximately $66 \mathrm{ft}$ ). Analysis of the shear stress at 100,000 ft $3 / \mathrm{s}$ (fig. 17) indicated that shear stresses would be highest near the outlet of the diversion channel. However, the shear stress values were less than Julien's (1998) shear stress values for bed movement, which would indicate no bed movement. This area is near a vegetated island (fig. 11) and no channel change has occurred in this area based on inspection of aerial photography taken in 1996, 2002, 2006, 2007, and 2011.

\section{Model Limitations and Sensitivity}

To evaluate the applicability of FaSTMECH to the two areas of concern along the Copper River Highway, the limitations of the model must be considered. These limitations are (1) the capabilities of FaSTMECH and (2) the quality and quantity of the required field data. FaSTMECH can compute the bed shear stress, and if bed-material data are available, the mobility of the streambed can be determined. The field data required to develop the models for the two areas of concern in this study consist primarily of topography, flow, and corresponding water-surface elevations. For the Mile 38-43 area, the 2009 LiDAR provided a good data set to construct the DEM. Comparison with the 2011 aerial photography showed only minor changes. Flow data from the streamgaging station at the Million Dollar Bridge are considered good, as are the water-surface elevations obtained at various flows at the various bridges. Water-surface elevations upstream of the bridges are based on the slope that was determined from the LiDAR data rather than by traditional surveying techniques. Additionally, the drag coefficient used is an average value, representing both vegetated areas and river channels. Thus, for water surface elevation and drag coefficient, some error likely was introduced.

For the Bridge 339 area, changes have occurred in the main channel toward Bridge 339 since the 2009 LiDAR data were collected. However, most of the area has not changed for the computational grid used to examine the diversion channel. Although, the water-surface elevations seem reasonable, no actual field data are available for comparison. Similar to work by Brabets and Conaway $(2009,2010)$, adjusting the drag coefficient plus or minus 25 percent changed the median water-surface elevations and velocities only slightly, indicating that these parameters are not sensitive to the selection of drag coefficient. Model-simulated shear stress changed proportionally with the drag coefficient, indicating the importance of first calibrating the model to the roughness, primarily to accurately simulate shear stress. 


\section{A. 50,000 cubic feet per second}

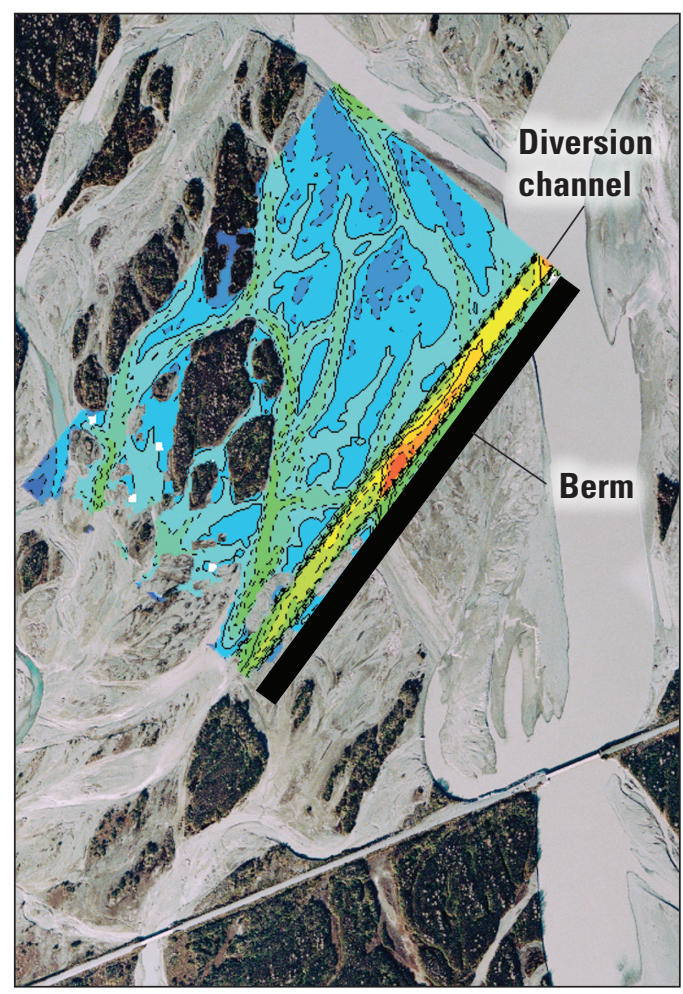

Aerial photograph taken by AeroMetric, Inc., October 4, 2011

\section{B. 100,000 cubic feet per second}

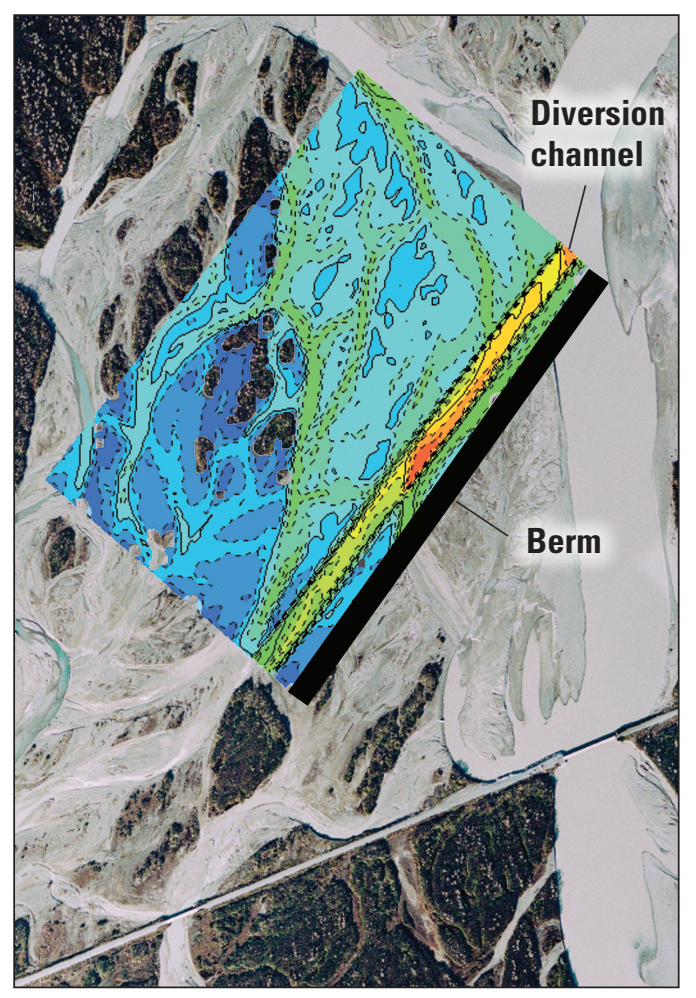

\section{EXPLANATION}

Depth, in feet
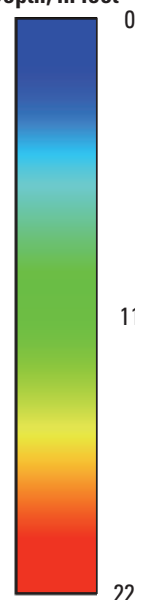

EXPLANATION

Depth, in feet
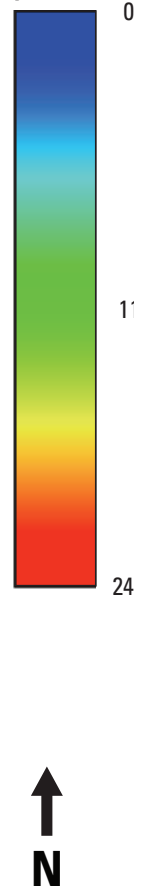

Figure 15. Output from FaSTMECH showing depth of water for flows of $(A) 50,000$ and $(B)$ 100,000 cubic feet per second for the Bridge 339 area, Copper River Highway, Alaska. 
A. 50,000 cubic feet per second

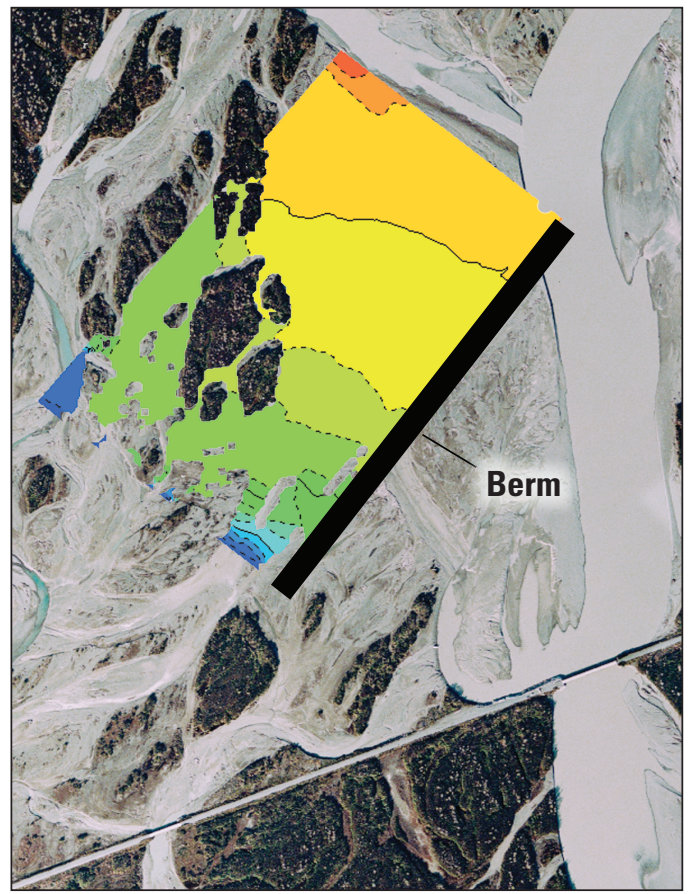

Aerial photograph taken by AeroMetric, Inc., October 4, 2011

\section{B. 100,000 cubic feet per second}

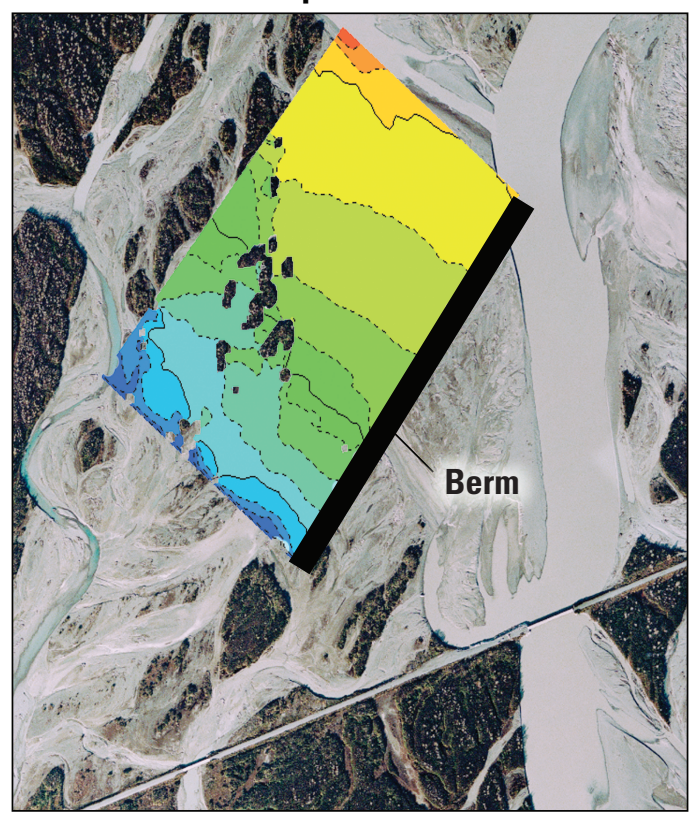

EXPLANATION

Water-surface elevation,

in feet above North

American Vertical

Datum of 1988

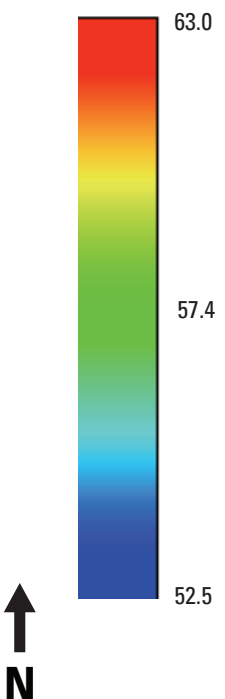

\section{EXPLANATION}

Water-surface elevation in feet above North American Vertical

Datum of 1988

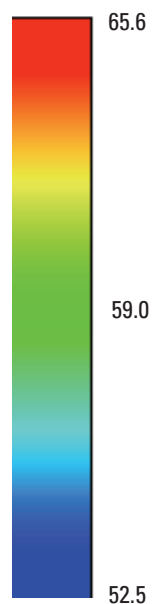

Figure 16. Output from FaSTMECH showing water-surface elevation for flows of $(A) 50,000(B)$ and 100,000 cubic feet per second for the Bridge 339 area, Copper River Highway, Alaska. 


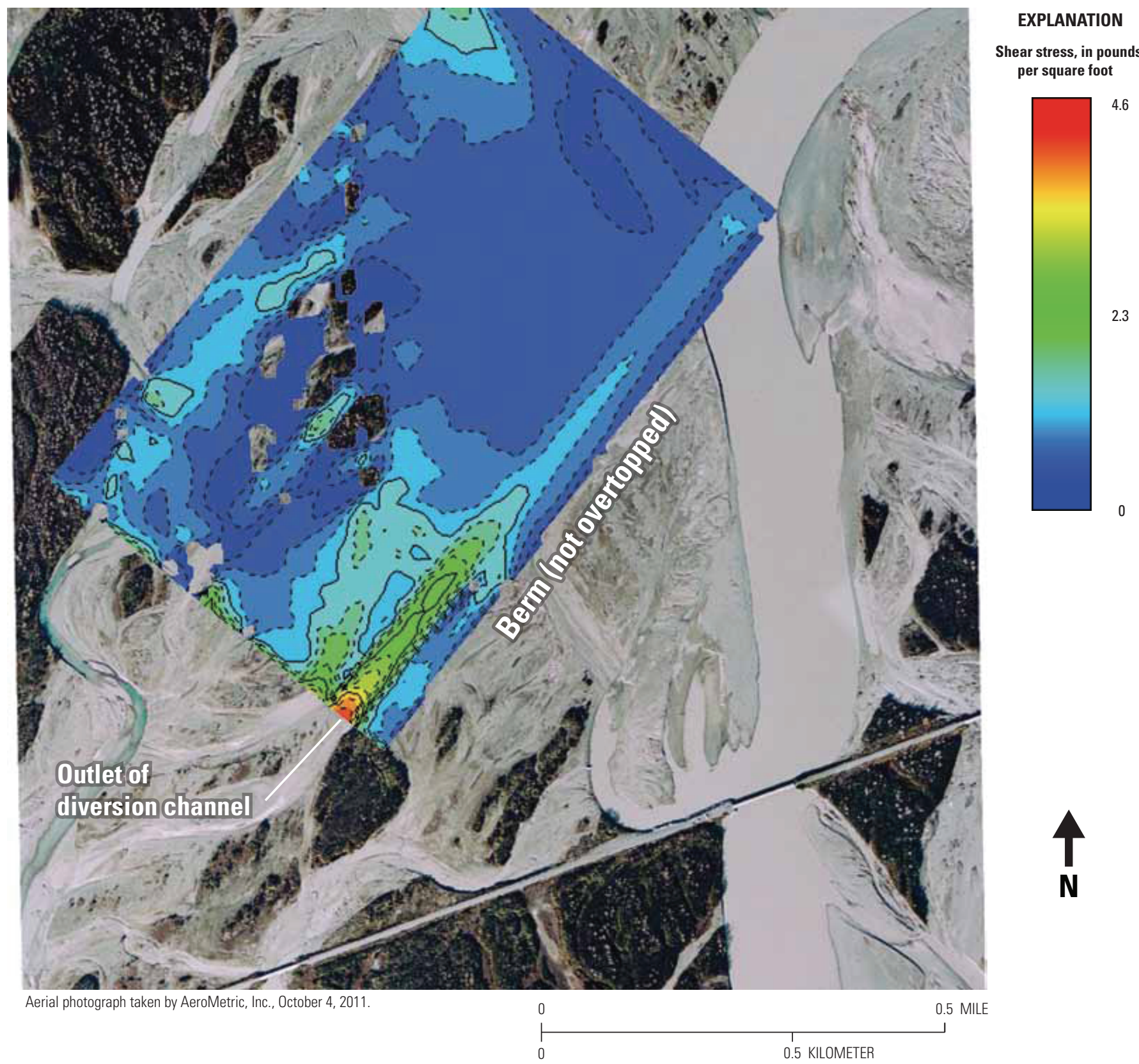

Figure 17. Output from FaSTMECH showing shear stress for a flow of 100,000 cubic feet per second for the Bridge 339 area, Copper River Highway, Alaska. 


\section{Summary and Conclusions}

Previous studies have documented the change and migration of the main channels of the lower Copper River, Alaska, with respect to the Copper River Highway and its bridges. Currently (2012), two areas of the Copper River Highway are threatened by channel migration. From Mile 38 to Mile 43, the grade of the highway is too low and the highway could be overtopped by high water. At Mile 36, the main channel of the Copper River has migrated directly toward Bridge 339, which is undersized to convey the flow. Beginning in 2011, measured flow at Bridge 339 was about 40 percent of the total flow of the Copper River. In mid-August 2011, flows through Bridge 339 increased to about 64 percent of the total flow of the Copper River. These excessive flows have caused as much as $50 \mathrm{ft}$ of scour near the piers of Bridge 339, severely undermining the capacity of the piers to absorb vertical and lateral loads and resulting in the closure of the bridge and highway.

The U.S. Geological Survey Flow and $\underline{\text { Sediment }}$

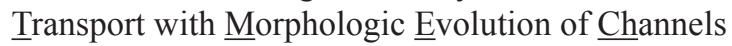
(FaSTMECH) model was used in this study to simulate water-surface elevation in the Mile 38-43 area for three flow scenarios to evaluate the effect of raising the road grade $5 \mathrm{ft}$. For flows of $116,000 \mathrm{ft}^{3} / \mathrm{s}$ and $174,000 \mathrm{ft}^{3} / \mathrm{s}$, FaSTMECH simulations indicated that the highway would not be overtopped; however, ponding would occur near Mile 38. For a flow of $400,000 \mathrm{ft}^{3} / \mathrm{s}$, FaSTMECH simulated water-surface elevations ranging from $59 \mathrm{ft}$ at Mile 38 to about $108 \mathrm{ft}$ at Mile 43. The current elevation of the road ranges from $66 \mathrm{ft}$ at Mile 38 to about $105 \mathrm{ft}$ at Mile 43. Thus, if the road grade were raised $5 \mathrm{ft}$, it would not be overtopped by a flow of this magnitude.

At the Bridge 339 area, FaSTMECH was used to analyze the hydraulic effects of constructing a channel to divert flow away from Bridge 339 toward Bridge 334, a 1,200-ft long bridge. FaSTMECH simulated depth, water-surface elevation, and velocity, for flows of 50,000, 75,000, and 100,000 ft $3 / \mathrm{s}$. Model simulation results indicated that the proposed channel could divert 100,000 $\mathrm{ft}^{3} / \mathrm{s}$ away from Bridge 339 and not overtop the constructed berm. The simulated velocities were used to calculate shear stress at the streambed. Shear stress simulations indicated that the bed is not likely to move at the end of the diversion channel. The ability of the model to simulate these improvements was somewhat constrained by the accuracy of estimated water-surface elevations and using an average value for the drag coefficient.

\section{Acknowledgments}

The author gratefully appreciates the support of the Alaska Department of Transportation and Public Facilities (ADOT\&PF) for this study, specifically Leo Woster, Jeff Stutzke, and Dave Bloom of the Northern Region ADOT\&PF, and Jack Stevenson of the Cordova Maintenance Facility of ADOT\&PF. This study was funded under the State of Alaska Project COPPER RIVER HWY MP 27-49 HYDROLOGY Study - AKSAS 61959.

\section{References Cited}

Brabets, T.P., 1997, Geomorphology of the Lower Copper River, Alaska: U.S. Geological Survey Professional Paper 1581, 89 p. (Also available at http://pubs.er.usgs.gov/ publication/pp1581.)

Brabets, T.P., and Conaway, J.S., 2009, Geomorphology and river dynamics of the Lower Copper River, Alaska: U.S. Geological Survey Scientific Investigations Report 2009-5257, 42 p. (Also available at http://pubs.er.usgs.gov/ publication/sir20095257.)

Brabets, T.P., and Conaway, J.S., 2010, Application of the multi-dimensional surface water modeling system at Bridge 339, Copper River Highway, Alaska: American Society of Civil Engineers, Proceedings of the Fifth International Conference on Scour and Erosion, November 7-10, 2010, San Francisco, Calif., Geotechnical Special Publication No. 210, p. 570-579.

Conaway, J.S., and Brabets, T.P., 2011, Streamflow and streambed scour in 2010 at Bridge 339, Copper River, Alaska, in Dumoulin, J.A., and Dusel-Bacon, Cynthia, eds., Studies by the U.S. Geological Survey in Alaska, 2010: U.S. Geological Survey Professional Paper 1784-C, 24 p. (Also available at http://pubs.er.usgs.gov/publication/pp1784C.)

Curran, J.H., Meyer, D.F., and Tasker, G.D., 2003, Estimating the magnitude and frequency of peak streamflows for ungaged sites on streams in Alaska and conterminous basins in Canada: U.S. Geological Survey Water-Resources Investigations Report 03-4188, 101 p., 1 pl. (Also available at http://pubs.usgs.gov/wri/wri034188/.)

Julien, P.Y., 1998, Erosion and sedimentation: Cambridge University Press, $280 \mathrm{p}$. 
McDonald, R.R., Bennett, J.P., and Nelson, J.M., 2001, The USGS multi-dimensional surface water modeling system, in U.S. Interagency Sedimentation Conference, 7th, Reno, Nev., 2001, Proceedings: U.S. Subcommittee on Sedimentation, p. I-161-I-167.

McDonald, R.R., Bennett, J.P., and Nelson, J.M., 2005, Multidimensional surface water modeling system user's guide: U.S. Geological Survey Techniques and Methods Report, book 6, section B, chap. 6, 156 p., accessed June 7, 2012 at http://wwwbrr.cr.usgs.gov/gstl/WebHelp_Pro/MD_SWMS. $\underline{\text { htm. }}$

Nelson, J.M., Bennett, J.P., and Wiele, S.M., 2003, Flow and sediment-transport modeling, in Kondolf, G.M., and Piegay, H., eds., Tools in fluvial geomorphology: England, Wiley, p. 539-576.
Nelson, J.M., and McDonald, R.R., 1997, Mechanics and modeling of flow and bed evolution in lateral separation eddies: Bureau of Reclamation, Glen Canyon Environmental Studies Report, 69 p.

Nelson, J.M., Shimizu, Y., Takebayashi, H., and McDonald, R.R., 2010, The international river interface cooperative (iRIC)_Public domain software for river modeling in Joint Federal Interagency Conference, 2nd, Las Vegas, Nev., June 27-July1, 2010, Proceedings: Federal Interagency Subcommittees on Hydrology and Sedimentation, 8 p.

Quinn, A.O., 1995, Iron rails to Alaskan copper-The epic triumph of Erastus Corning Hawkins: Bend, Oreg., Maverick Publications Inc., 195 p.

Wahrhaftig, Clyde, 1965, Physiographic divisions of Alaska: U.S. Geological Survey Professional Paper 482, 51 p., 6 pls. 
Publishing support provided by the U.S. Geological Survey

Publishing Network, Tacoma Publishing Service Center

For more information concerning the research in this report, contact the Director, Alaska Science Center

U.S. Geological Survey

4210 University Dr.

Anchorage, Alaska 99508-4560

http://alaska.usgs.gov 


\section{एँ}

品

离 